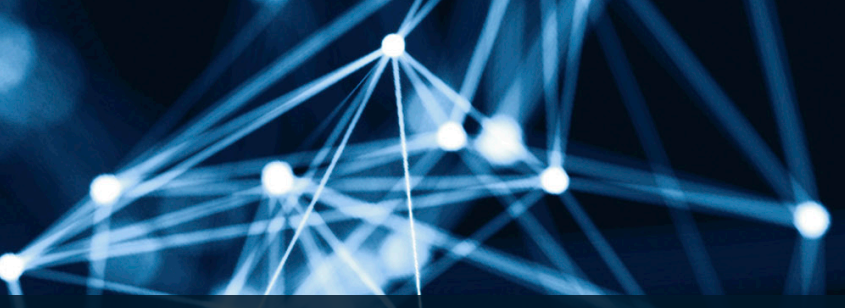

Report from the EU H2020 Research Project Ps2Share: Participation, Privacy, and Power in the Sharing Economy

\title{
Millennials and the Sharing Economy: European Perspectives
}

Giulia Ranzini, VU Free University Amsterdam Gemma Newlands, Norwegian Business School BI Guido Anselmi, University of Milano-Bicocca Alberta Andreotti, University of Milano-Bicocca Thomas Eichhorn, University of Leipzig Michael Etter, Copenhagen Business School Christian Hoffmann, University of Leipzig Sebastian Jürss, University of Leipzig Christoph Lutz, Norwegian Business School BI 
Report from the EU H2020 Research Project Ps2Share:

Participation, Privacy, and Power in the Sharing Economy

\section{Millennials and the Sharing Economy: European Perspectives}

Giulia Ranzini ${ }^{1}$, Gemma Newlands $^{2}$, Guido Anselmi ${ }^{3}$, Alberta Andreotti ${ }^{3}$,

Thomas Eichhorn ${ }^{4}$, Michael Etter ${ }^{5}$, Christian Hoffmann ${ }^{4}$, Sebastian Jürss ${ }^{4}$, and Christoph Lutz ${ }^{2}$

${ }^{1}$ VU Free University Amsterdam

${ }^{2}$ BI Norwegian Business School

${ }^{3}$ University of Milano-Bicocca

${ }^{4}$ University of Leipzig

${ }^{5}$ Copenhagen Business School 


\section{Table of Contents}

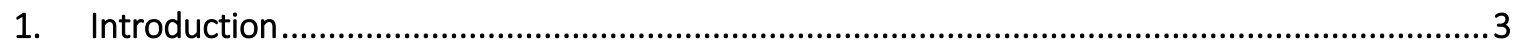

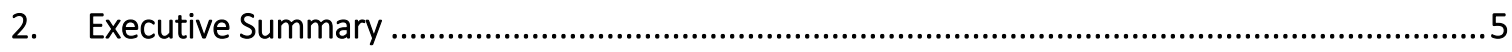

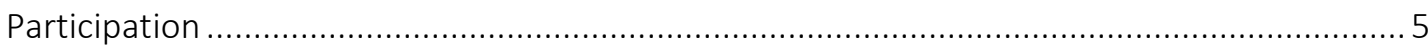

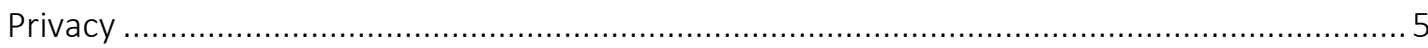

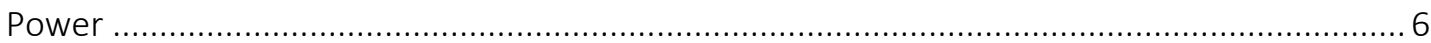

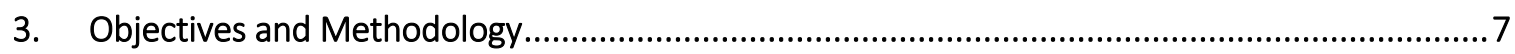

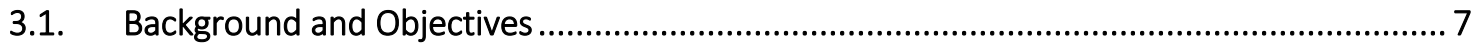

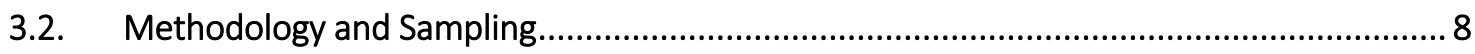

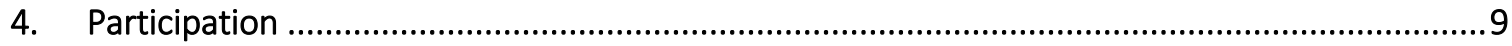

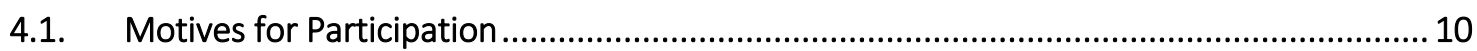

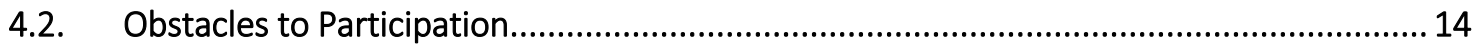

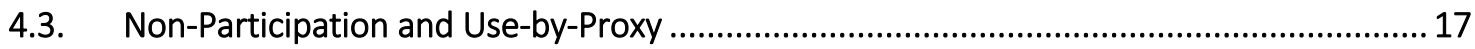

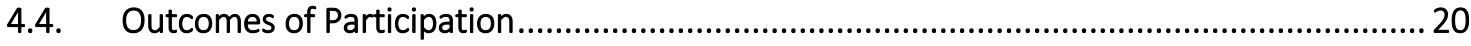

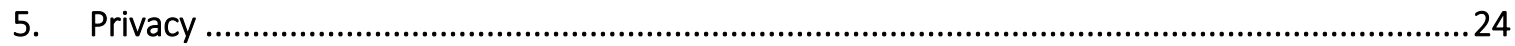

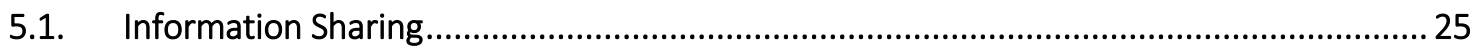

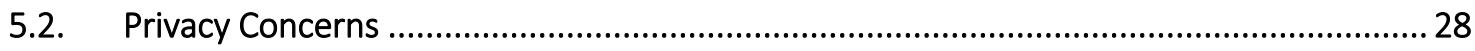

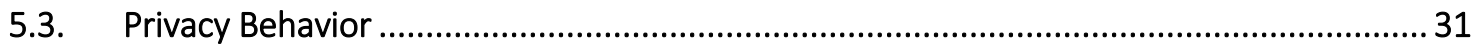

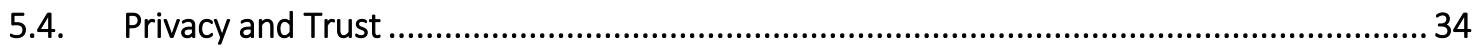

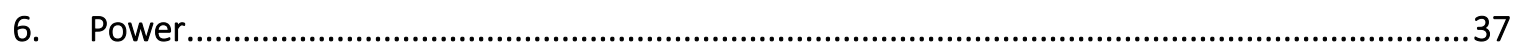

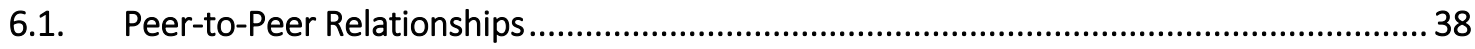

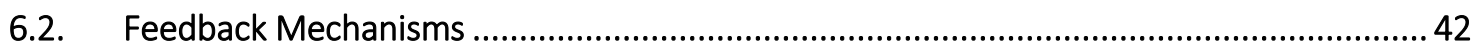

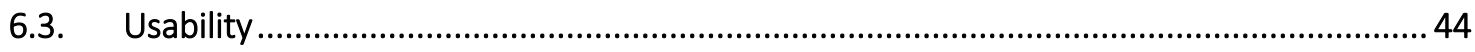

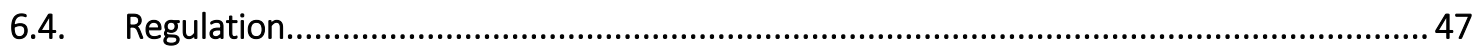

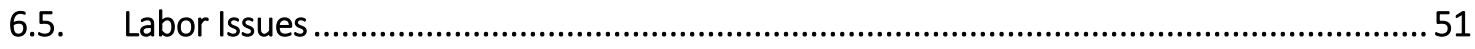

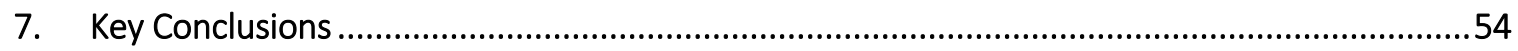

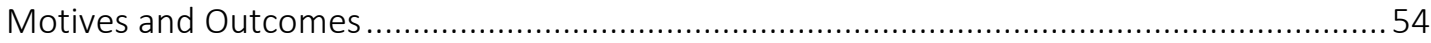

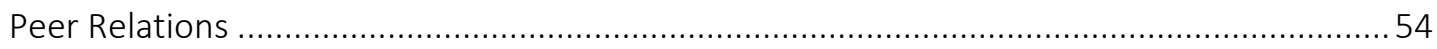

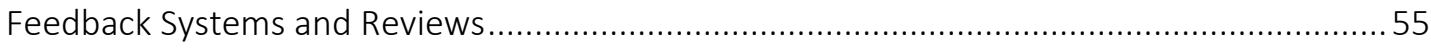

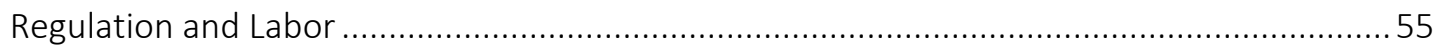

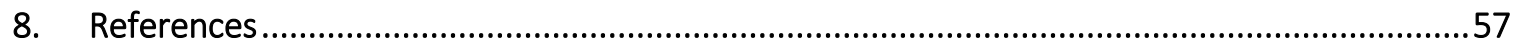

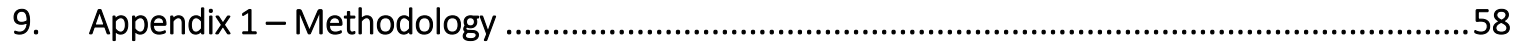

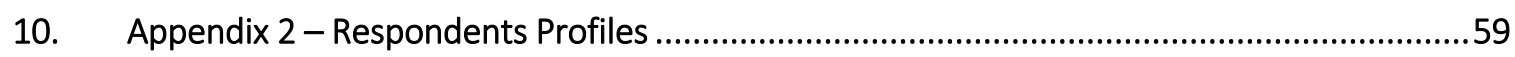

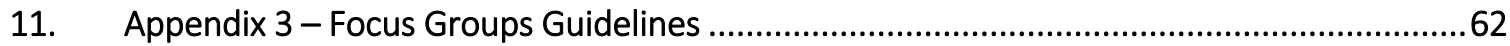




\section{Introduction}

In the last years, the sharing economy has emerged as an alternative to traditional exchanges, introducing the idea that users can grant other users temporary access to their goods and services for economic compensation. This shift was made largely possible by technological evolutions: Sharing platforms, which match users who share (providers) with users willing to pay for access (consumers), are based online and many services are available exclusively through a smartphone.

The nature of the sharing economy, aimed at least initially at co-consumption, and its technological dependency have led both media and academic outlets to link it strongly to the so called 'Millennial generation' (Anderson \& Rainie, 2010; Belk, 2014; Godelink, 2017). Born between 1982 and $1996^{1}$ and having lived through an economic crisis as either teenagers or young adults, Millennials have so far shown somewhat divergent consumption patterns when compared to older generations. Previous research has shown that Millennials in the US, for instance, are less likely to be homeowners (Xu, Johnson, Bartholomae, O'Neill, \& Gutter, 2015) and are more likely to choose public or shared transportation over owning their own car (Klein \& Smart, 2017). It is therefore not surprising that Millennials have been identified as 'driving' the growth of the sharing economy (Maycotte, 2015).

Aiming to directly approach the experience of consumers in the sharing economy, this report presents the results from an in-depth analysis of qualitative data which emerged from 18 focus groups conducted concurrently across six European countries (Germany, Italy, The Netherlands, Norway, Switzerland, and The United Kingdom). Our findings, based on a sample of Millennial consumers of the sharing economy, paint a picture of the meanings, expectations, and obstacles which emerge from interacting with peers and platforms.

This report is part of a European Union Horizon 2020 Research Project on the sharing economy: Ps2Share 'Participation, Privacy, and Power in the Sharing Economy' (www.ps2share.eu). The initial stage of this Research Project involved a set of three literature reviews of the state of research on three core topics in relation to the sharing economy: participation (Andreotti, Anselmi, Eichhorn, Hoffmann, \& Micheli, 2017), privacy (Ranzini, Etter, Lutz, \& Vermeulen, 2017), and power (Newlands, Lutz, \& Fieseler, 2017a). The second step consisted of a series of focus groups conducted across six European countries, the results of which are presented in this report. The third step consisted of a large-scale survey of citizens of twelve European countries, the results of which are to be found in three separate reports, covering privacy in the sharing economy (Ranzini, Etter, \& Vermeulen, 2017), participation in the sharing economy (Andreotti, Anselmi, Eichhorn, Hoffmann, Jürss, \& Micheli, 2017), and power in the sharing economy (Newlands, Lutz, \& Fieseler, 2017b).

This report, focusing solely on the focus group analysis, is structured around the three themes covered by the EU Horizon 2020 Ps2Share Research Project: Participation, Privacy, and Power. The report commences with an executive summary and a brief overview of our methodology and objectives. Following on, chapter 4 focuses on participation and covers consumers' motives and obstacles for operating in the sharing economy. Chapter 5 covers our analysis of privacy topics and

\footnotetext{
${ }^{1}$ Source: US Census (https://www.census.gov/newsroom/press-releases/2015/cb15-113.html).
} 
includes consumers' perceived risks and defensive behaviors. Chapter 6 focuses on power and reports on what consumers perceive as the challenges and power-dynamics of the sharing economy. The report closes with a discussion of key conclusions, drawn from across the differentiated topics. More details about the methodology, as well as a description of participants and the focus group guidelines, can be found in the Appendices. 


\section{Executive Summary}

Several interesting findings emerged from each of the themes of our project, providing a unique overview on the perspectives of Millennial consumers within the sharing economy.

\section{Participation}

- When assessing respondents' drivers of participation within the sharing economy, we found that economic motivations were prioritized over non-economic motivations. Most respondents were interested in sharing platforms only when platforms offered a more cost-effective alternative to traditional services. Additional drivers of participation included convenience and social interactions. However, these appeared to be only secondary to potential economic advantages.

- For Millennial consumers, obstacles to participation were mostly related to a lack of technical access, either because services were unavailable, or because information about services was inaccessible and difficult to find.

- Respondents also mentioned the potential for privacy invasion or discrimination by providers as sources of discomfort. However, these potential discomforts were not sufficient to hinder participation.

- Participation-by-Proxy emerged as a form of indirect use of sharing platforms. Individuals unfamiliar with technology or unwilling to share personal data could use sharing platforms through their friends' and relatives' accounts.

- When queried about the outcomes of participating in the sharing economy, respondents mostly referred to economic advantages and interpersonal benefits from social interaction. Limited reflection occurred about the societal outcomes of interacting on sharing platforms.

Privacy

- Focus group respondents highlighted four main attitudes towards sharing their private data. Optimist respondents reported feeling that data sharing was helpful to the organizations. Negotiators seemed to only provide the data which was essential to access the service. An attitude coded as inevitability characterized consumers who felt that providing data was an unavoidable price for access in the sharing economy. An extreme version of this attitude was coded as cynicism for users resigned to a complete lack of control over their data in modern society.

- Privacy concerns appeared to be more about interaction with peers, than about potential platform misuse of data. Respondents reported concerns over the potential for boundary breaches outside the platform, both online and offline. 
- In order to access services, respondents strategically share the data that can make them more attractive to specific providers. These efforts, aimed at projecting trustworthiness and respectability, take place both on public profiles and through direct messaging.

- In order to reduce their risks from interacting with other users, respondents observe carefully the profiles of providers and, in particular, the pictures and words used both in public and private messages. Ratings and reviews are considered to be valid elements for avoiding fraud.

- The role of feedback systems was also considered essential when it comes to establishing trust, which helps consumers overcome their privacy concerns. A system which is perceived to function well helps consumers find providers trustworthy, which in turn improves the trustworthiness of platforms.

\section{Power}

- One of the reported costs emerging from power imbalances comes from emotional regulation. Respondents felt as if they had to behave coherently with emotional/social expectations, for example, by being social and affable or by providing entertainment and small talk.

- Respondents identified discrimination as a relevant power imbalance within the sharing economy. Interestingly, they expressed discomfort towards systemic platform discrimination but a more nuanced attitude towards discrimination carried out by providers, which is occasionally perceived as justified.

- Feedback systems (such as ratings and reviews) were a recurrent topic of conversation among respondents. The main points of discussion were the reviews' fairness (often perceived as lacking), accuracy (considered to be skewed towards positive judgment), and reciprocity (considered mostly as a guarantee of quality).

- Respondents appreciated the usability and transparency of platforms, but reported an underlying sense of uncertainty, especially when it comes to home-sharing services.

- Regulatory concerns also emerged from respondents who appeared to be worried about the sometimes questionable legal status of sharing platforms. The professionalization of sharing platforms was also reported as both an unavoidable eventuality and a risk for the authenticity of experiences.

- Regarding providers, respondents identified their role as entrepreneurial rather than as employees of the platforms. Still, concerns were raised around behavioral nudging from the platform and working conditions, especially for workers within ride-sharing services. 


\section{Objectives and Methodology}

\subsection{Background and Objectives}

Depending on their own individual attitudes and motivations, as well as on external factors such as cultural, political, and regulatory contexts, users assign different meanings to the sharing economy. Understanding the direct experiences of users, therefore, is essential for comprehending aspects such as motivations for participation, attitudes towards sharing data and physical spaces, and perceptions of power imbalances during interactions.

As such, we recognized the importance of approaching consumer experiences as directly as possible. We determined to not only use a qualitative approach, but also employ a framework of semistructured focus groups, which would allow respondents to posit their own questions and divert the thread of conversation towards themes which they found most interesting and personally relevant.

Our respondent sample was selected on the basis of their experience with the sharing economy and within an age range from 20 to 35 years old. Belonging to the so called 'Millennial generation' suggested a greater familiarity with the technologies required to access sharing platforms, as well as a positive attitude towards sharing-based business models (Godelnik, 2017). We found that, while the former was true for almost the totality of respondents, the latter was not necessarily the case for all the interviewed Millennials.

We also made a conscious choice to conduct our focus groups within urban areas. Important issues of the sharing economy, such as the impact of ride-sharing and accommodation-sharing services on city rental prices and urban traffic suggested that an urban context would provider richer data. Moreover, for a generation which seems to find the symbols of financial independence (such as home ownership) more difficult to achieve than previous generations, the sharing economy is both an opportunity and the source of many challenges.

While the overall aim of this research was to explore how European Millennial consumers experience the sharing economy, the detailed objectives of this study were to investigate:

- Consumers' overall perception of the sharing economy.

- The motives and obstacles of participation in the sharing economy.

- The motives of non-use, or of interrupted use of platforms.

- Consumers' attitudes towards data sharing.

- The privacy concerns of consumers and their risk reduction strategies.

- How consumers establish trust towards peers and platforms.

- What power dynamics take place in peer-to-peer relationships.

- Consumers' perceptions of feedback mechanisms and reviews.

- Regulatory concerns and consumer perceptions of their own and others' labor. 


\subsection{Methodology and Sampling}

The methodology used for this research consisted of qualitative interviews collected through eighteen focus groups, covering the topics of participation, privacy, and power. The focus groups took place in six European countries: Germany, Italy, The Netherlands, Norway, Switzerland, and The United Kingdom. The countries were selected in order to achieve a geographical spread across Europe and reflected the constitution of the research consortium. A detailed research design and technical summary is provided in the Appendix. 


\section{Participation}

Among Millennials, participation in the sharing economy is usually connected to the experience of transportation, travel, or holidays. As such, Millennial participants gravitate towards sharing platforms which offer transport and accommodation. Visiting a new place is often given as the context for when participants enter the sharing economy for the first time. Economic motivations are also predominant over non-economic motivations. Accordingly, our sample of Millennial consumers values the budget-friendliness of platforms over other aspects of platforms, such as their uniqueness or the opportunity to interact with hosts.

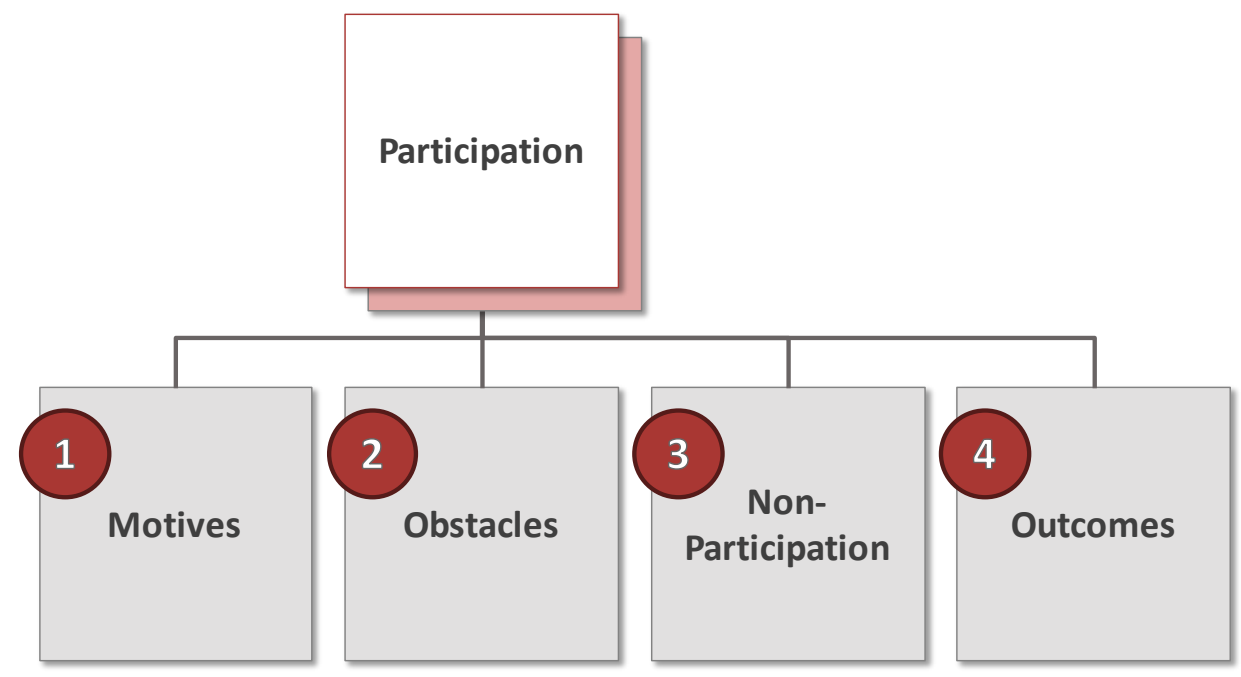

Figure 1: Participation - Main Code structure

Focus group respondents highlighted three main motivations for engagement towards sharing economy platforms. Most importantly, economic imperatives determined whether and how intensively Millennial consumers participated in the sharing economy. A limited budget could, in fact, lead consumers to be more engaged with the platforms as a locus for scouting more affordable and sustainable services. Reciprocity also fostered engagement, since pleasant encounters motivated consumers to provide ratings and reviews more diligently and more extensively. Finally and paradoxically, privacy concerns could also lead consumers to be more engaged, since participants invested more time in collecting, filtering, and analyzing the information available on sharing platforms.

The vast majority of our focus groups respondents reported a high rate of adoption of multiple sharing economy platforms. We identified only a few cases of non-participation, primarily due to nonavailability of services. One interesting finding, in this sense, concerns use-by-proxy. Respondents often operated third party profiles for friends and family who could not, or did not wish to, be on the platforms themselves. We identified obstacles to participation which mostly coincided with a lack of available information (e.g., not knowing that a service exists, or not knowing anyone who is familiar with a service) and with the availability of cheaper or free alternatives. Overall, reputation systems provided by platforms were met with high levels of acceptance. In some cases, respondents reported 
that a desire to protect personal boundaries (both digital and physical) prevented them from more intensive participation.

Our respondents were primarily aware of individual-level outcomes of the sharing economy. Discussions focused on money-saving, increased choice, convenience, and, to a lesser degree, social interaction. Sharing services do not appear to foster social capital, as social interactions tended to remain fleeting. At a higher level, participants critically discussed the growth and increasing professionalization of sharing platforms, which diminishes the non-economic benefits of the sharing economy (fun, social interaction, sustainability, etc.). Millennial consumers acknowledge that a growing sharing economy requires adequate regulation and taxation - but also fear that regulation might be harmful, and lead to limited choices and higher prices. As such, our respondents see individual-level outcomes as more pressing than societal ones.

\subsection{Motives for Participation}

Four main motives for participation in the sharing economy emerged from our analysis: Economic, convenience, social interaction, and reciprocity.

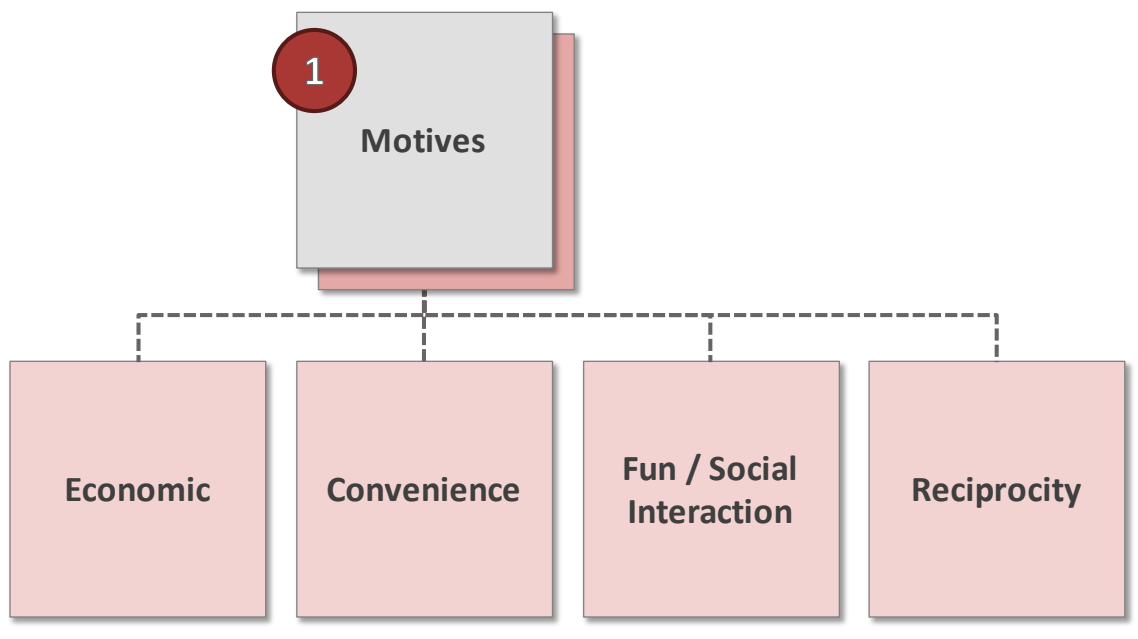

Figure 2: Code Structure for Motives of Participation

Millennial consumers associate sharing services mostly with travel, either to reach a holiday destination or purely as transport (e.g., between their home town and their place of work or study). Within this general framing of sharing services, motives for participation in the sharing economy can be differentiated between economic and non-economic. In terms of economic motives, cost-cutting is a key argument.

"During my undergraduate studies, I frequently took people home or close by. And frequently, I really drove for free, if you like. Because as soon as you had two or three..., just two people, really, in your car, you had the margin you need to fill the tank and then some." (M, 25, Germany) ${ }^{1}$ 
"Uber also, big fan of Uber. I used it in Amsterdam, which is actually not a lot cheaper than the regular taxis. But when you use it outside of the Netherlands, when you use it, let's say, in the United States, it'll be a lot cheaper." (F, 21, Netherlands)

Cost-cutting can drive not only the decision to participate in the sharing economy, but also the level of participation. Respondents highlighted how their investment of time and energy on the platform was connected to the value they derived from it. If a traditional service was similarly affordable, but required less input from users (in terms of time spent browsing alternatives, personal information disclosed, etc.), respondents still viewed it as more favorable.

"I want real value for money. When it comes to Airbnb, once I'm on the platform I look at a thousand things and then I just choose what is most price-worthy because...if I compare it with a standard service, l expect the sharing economy to be cheaper, because it's based on trust. I mean, if there is a (comparably cheap) service in which I don't have to share anything, I'll pick that one instead (of the sharing economy)."( $M, 24$, Italy) ${ }^{2}$

The importance of cost-cutting is an interesting finding when reflected in terms of the outcomes of the sharing economy. In fact, if sharing services primarily serve to enhance efficiency and cut costs, this implies (1) a disruption to established services and (2) relatively low margins per transaction. Cost pressure, therefore, would be exerted both on existing services and on those active in the sharing economy.

A second economic motive for participating in the sharing economy is to receive additional income. This is related to cost-cutting but can be seen as a stand-alone motive, especially when consumers think about what could motivate providers to participate in the sharing economy.

"I knew Airbnb because a friend was renting her house because they needed the money." (F, 30, Netherlands)

Not many respondents used the sharing economy for this purpose themselves, but they discuss this possibility as a feature of sharing platforms.

"I think that sharing economy is about like a part-time job that people can do to earn a little bit of money at the end of the month." (M, 22, Norway) 
"Well it is really, how should I say, commercial in how it is set up, I think-also in the case of Airbnb. And the people, although they are private individuals, but they really created a second source of income." (M, 26, Germany) ${ }^{3}$

Among the non-economic, but instead functional motives for participation, an important one is convenience. This holds especially true for large, international sharing services. When traveling, Millennials experience it as especially convenient to use familiar services, such as Airbnb, Uber, or Blablacar rather than having to familiarize themselves with domestic services.

"But actually when I was abroad for my Erasmus program I used Blablacar and it was far easier than using the local trains. Compared to Italy, at least...there I didn't know the train system or the language, so it was easier to use Blablacar." (F, 23, Italy) ${ }^{4}$

Another non-economic motive frequently discussed by respondents is fun and social interaction. Participants highlighted how the human side of the sharing economy might provide value over traditional alternatives. For example, they reported enjoying conversations with drivers while ridesharing or with hosts while couch-surfing.

They also enjoyed the sense of authenticity which most sharing services provide. Travelling experiences in the context of sharing services are seen as more authentic, as participants benefit from a glimpse into local hosts' residences or means of transportation.

"And sometimes you even get to hang out if they're like really nice people. You get to hang out, you get to eat together whatever, and maybe have some contacts abroad afterwards." (F, 20, Netherlands)

"And actually with city trips or something, where I have preferably used AirBnB. With something like that, you really have the feeling that you get to know it in a cooler way. You live a bit more authentically. So this whole image thing that they play on, really works, I think. That you have the feeling of being a bit more involved. You live in a regular house and not in some hotel complex. And you can cook there and go out very naturally and shopping and so on. I would say that you have much more of the feeling to be a regular part of the city if you go to a supermarket, instead of always eating out or something. So I feel like it is a new alternative for traveling. To get to know a city in a more authentic and somehow younger way." (F, 24, Germany) ${ }^{5}$

The reciprocity of interaction seems to motivate participation among Millennial consumers. Respondents named it as a reason to interact more extensively with the platform, for example, 
through providing more extensive reviews. Deeper or more frequent personal interactions also seem to positively affect levels of participation:

"I have to say that it is very important to me to write reviews on Airbnb. (...). Somebody is giving you access to their apartment and a bit also to their world, and many really put in an effort, providing towels and so on. And then, I think, this comment is some kind of appreciation and somewhat of a little thank you." (F, 24, Germany) ${ }^{6}$

Non-economic motives for participation, beyond convenience, fun, and social interaction were only reported by respondents once prompted. In these instances, participants discussed the benefits of resource sharing, of alternative economic models, and of increased sustainability. This was, however, generally approached in rather abstract terms.

"If for example I just take Airbnb, like people have a scale of being a host to, like, having an apartment, so they're not only helping themselves but they're helping other people that they can stay. So, it's kind of like the sharing and utilizing of each other's resources." (M, 20, Norway)

Interestingly, respondents identified sustainability as a motive for participation, when connected to its early stages. As services become more professionalized, non-economic motives are gradually replaced by economic ones.

"It has probably started with the basic idea to use resources more rationally, but it has become commercialized and professionalized because people have realized: Ok, I can use it somehow to my advantage." (M, 25, Germany) ${ }^{7}$

"I also think the aspect, this societal prosperity and this abundance of things we possess, but not necessarily need, was the starting point of the whole thing. And of course, many companies have made use of it sooner or later and have jumped on the bandwagon." ( $M$, 26, Germany) ${ }^{8}$

In the focus groups, we asked respondents about their reasons for quitting sharing economy platforms, if applicable. While none of the participants had entirely exited the sharing economy, some reported their reasons for leaving individual platforms. In this case, economic motives were predominant over non-economic motives. The most frequently named reason for exiting (or switching) platforms was increased costs of the service or decreased costs of a substitute. In some cases, a change in pricing negatively affected the non-economic evaluation of the platform as well. 
For example, stricter payment systems may be experienced as a "commercialization" of a platform², making it less of a social or fun environment.

"On the other hand, at Blablacar, for example, it also changes as trips are getting more and more expensive. Trips that were offered for 12 euros or so in the beginning now cost almost as much as a train ride on some days. So when I weigh my options, whether I take the train or Blablacar, I do not always have a big cost advantage." (F, 22, Germany) ${ }^{9}$

Finally, in some instances, participants quit a service for convenience's sake, if the service or its handling becomes too cumbersome, or if more convenient substitutes arise.

"[l stopped using Uber] when I changed my phone, I didn't download the app again and l ended up finding other ways to move around. You have your usual travel and then there are unforeseen situations, in which case you can just download the app again, and then that's it." (M, 24, Italy) ${ }^{10}$

This reason for quitting reinforces the framing of the sharing economy as a budget alternative to established services. Consumers expect sharing offers to be perhaps somewhat less comfortable, but cheaper than regular services. Once prices of traditional and sharing economy options become similar, respondents report an intention to switch to the more comfortable alternative.

\subsection{Obstacles to Participation}

The obstacles for participation that emerged from our analysis are: Availability of sharing services, information access, informal alternatives, discrimination, and privacy concerns.

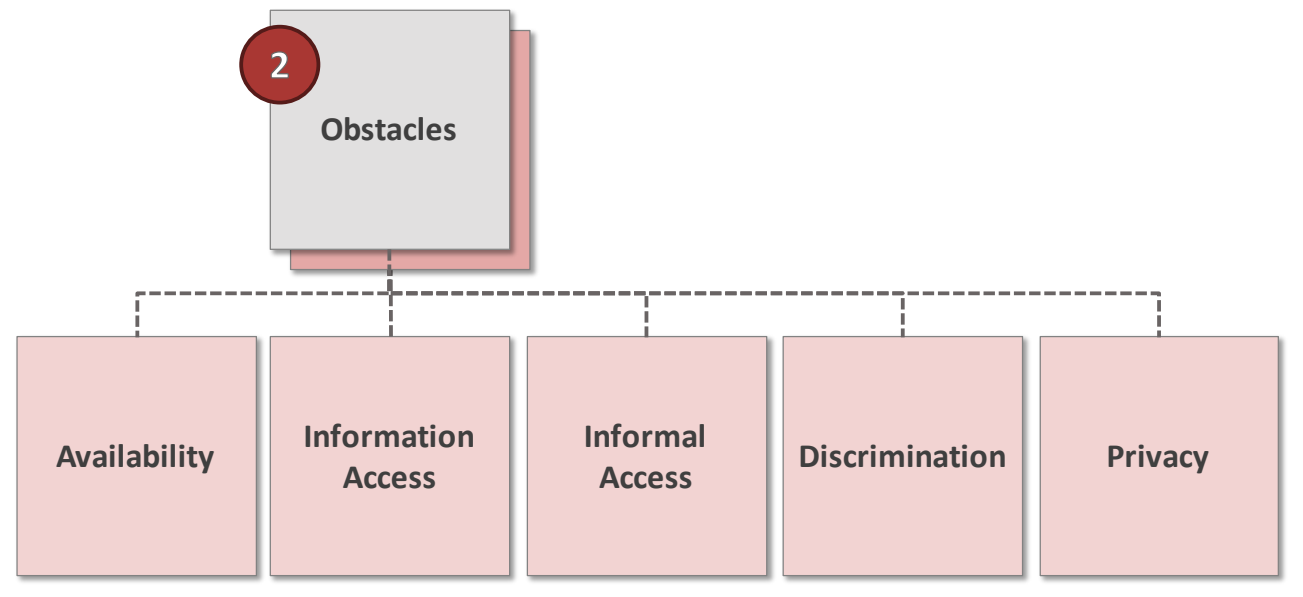

\footnotetext{
${ }^{2} \mathrm{~A}$ more in-depth discussion of the commercialization of platforms is available in chapter 6.4 .
} 


\section{Figure 3: Code structure for Obstacles to Participation}

An obvious obstacle to participation in the sharing economy is a lack of availability of sharing services. This can happen when sharing platforms are not (yet) available in a specific country, perhaps because of adverse local regulations, as is case for Uber. Even within individual countries, the availability of services is not always consistent, with a notable divide between urban and rural areas (also covered in the next section).

"It's about being familiar with these platforms. In big cities people know about these things, you have the one friend who knows about Airbnb. But in my small town, in my small network, everyone goes to the same old hotel, because that's just what you do." $(M, 24, \text { Italy })^{11}$

Within our sample, a lack of skills or capabilities was rarely reported as an obstacle to participation within the sharing economy. However, lack of access to information, emerged as important potential obstacle to participation. This begins with the introduction to the sharing economy, where personal recommendations play an important role in participants' decisions to sign up for a sharing service. Friends experienced with a sharing service are frequently consulted when deciding on whether to adopt a service or on which service to choose. Frequently, participants enter the sharing economy as users-by-proxy, i.e., as company to the person actually engaged in the digital and economic transaction.

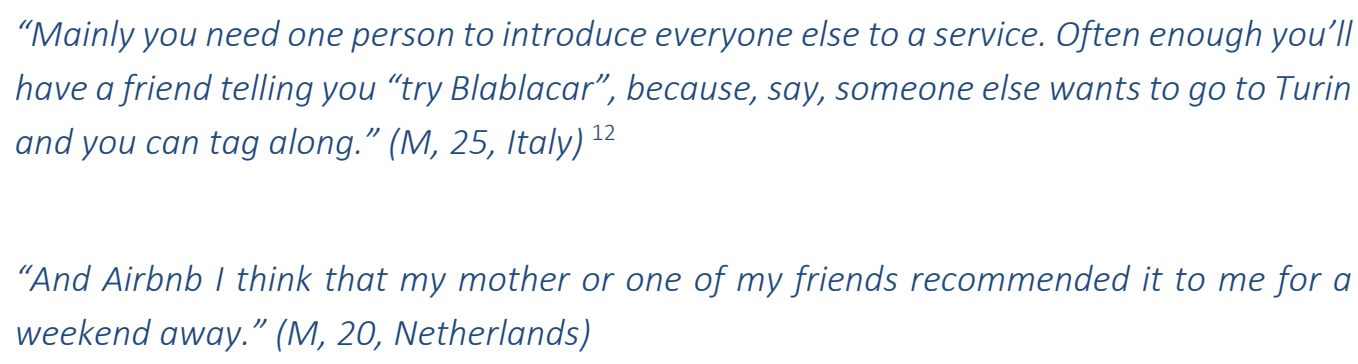

While recommendations from social contacts can be essential for users to participate in the sharing economy, they can also provide obstacles when they are the source of informal alternatives to the sharing platforms. In some cases, respondents highlighted how they found that they do not need to use a platform to share services or goods, as they usually share their goods with relatives or friends.

"When I travel to university, here in Milan, I usually share my car with some other students who come from the same town. We just have this agreement that when we commute, we share the ride." $(M, 25 \text {, Italy })^{13}$ 
"Recently I have hosted a friend of friends, like an impromptu Couchsurfing. He was coming to Milan and was in need of an accommodation so [...] my friends asked me if I can help. I met the guy, I left him my room and told him 'feel at home, here are the bed sheets'." (F, 24, Italy) ${ }^{14}$

Based on responses, there seems to be a trade-off between the value derived from social relations and users' participation in a sharing service. If goods, transportation, or accommodation are available through the informal network of users, they will rather employ those than seek the sharing economy alternative. This could also explain the popularity of sharing economy services among urban Millennials, who might have relocated and therefore not be able to rely as extensively on their personal networks.

As mentioned above, another obstacles to participation based in the social dynamics of sharing services are potential infringements to personal boundaries ${ }^{3}$. Some consumers might simply not want to interact with service providers on a personal level. In other instances, service providers may breach privacy or personal boundaries of sharing consumers, leading to less willingness to participate in the sharing economy.

"[A friend and] I went to Denmark last month and we were hesitating between discovering Couchsurfing and taking Airbnb. So we checked the Couchsurfing ads, and that was quite rich because we saw there were a lot of gay men that were proposing their housing and the description, it was written with things like, 'If you don't mind, we can sleep together.' Like that. (...) So for us, that was -- I mean we don't have anything against that, but it made our choice." (M, 20, Norway)

The diligence invested in collecting, filtering, and analyzing information, some based on reputation mechanisms, can lead to active discrimination ${ }^{4}$, both of providers and of consumers. Respondents reported occasional experiences of discrimination based on race, gender, or sexual orientation.

"I think I had requested two apartments in [German city], the first one was refused, but it was apparently, or rather I believe, that it was just - so it was a woman, who also lived in the flat-and she just wanted to have a female person. But that was actually the only time. Otherwise the bookings were always confirmed." (M, 26, Germany $)^{15}$

\footnotetext{
${ }^{3}$ See also: Chapter 5.3

${ }^{4}$ See also: Chapter 6.1.
} 
"It actually happened last year, my husband tried to book an Airbnb and then they declined. And then I tried to book it and they accepted. It was really strange. My husband is black. I don't want to jump up and say, "Oh it's a black thing" or anything like that, but the thing was, the story that he had was exactly the same as mine. " (F, 30, Netherlands)

In general, skills or capabilities do not seem to affect Millennials' levels or intensities of participation. Firstly, most participants reported only low-level engagement with the platforms they employed. Secondly, most participants tended to feature relatively high Internet skills. Thirdly, participants described sharing platforms as rather intuitive and easy to use.

Skills played more of a role in the context of privacy and information sharing ${ }^{5}$. These are key components of sharing engagement, as sharing participation is largely comprised of creating personal profiles, engaging with peers, and collecting and evaluating information. Respondents emphasized how informational skills are of critical importance for participation in the sharing economy. Those missing the ability to filter and to cross-validate information between different reputation systems might be more vulnerable to negative experiences, or steer away from sharing services all together.

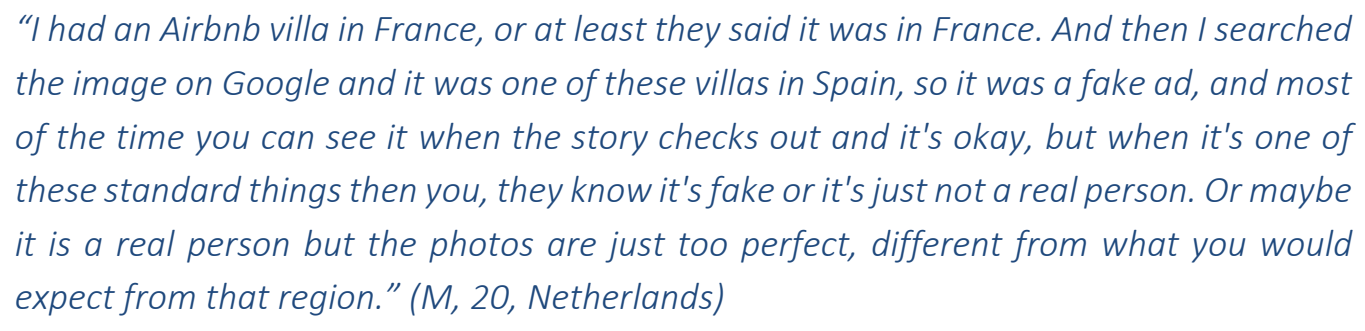

\subsection{Non-Participation and Use-by-Proxy}

Reasons for non-participation can be categorized into the lack of availability of sharing services, a lack of resources to participate, and the tendency to approach sharing services through use-by-proxy.

\footnotetext{
5 See also: Chapter 5.
} 


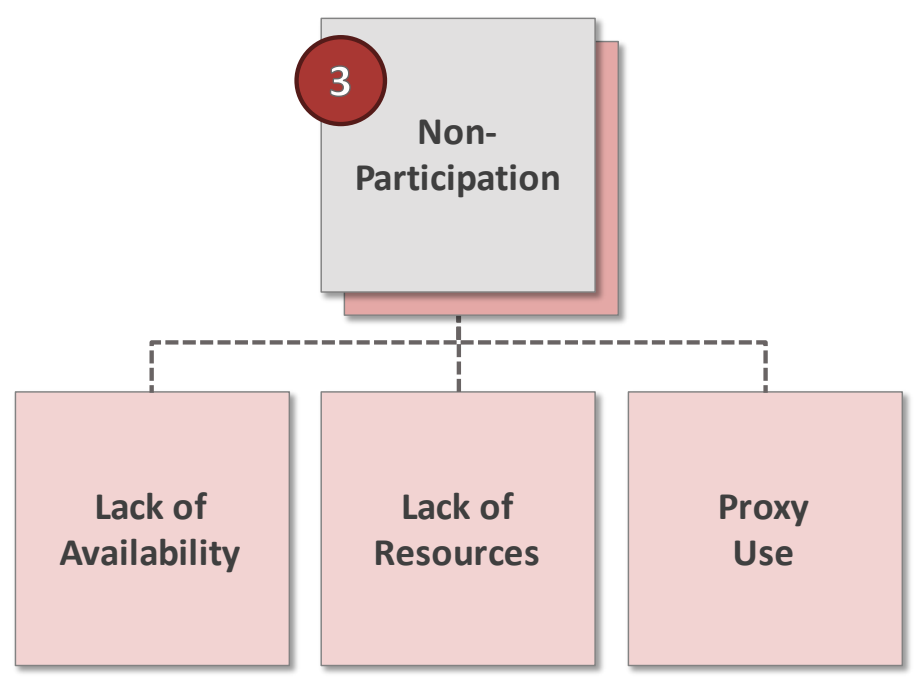

Figure 4: Code Structure for Non-Participation

According from our focus group respondents, familiarity with the sharing economy is high among Millennials, since many of their peers have engaged in consumptive uses of sharing services. However, some instances of non-participation in the sharing economy remain. Two forms of nonparticipation were identified as most recurrent. On the one hand, users are excluded because of a lack of service availability, or of individual resources. On the other hand, some users do not directly interact with sharing services, but might occasionally use them through someone else's profile (usersby-proxy).

The available data points to significant differences in terms of sharing service accessibility between participants living in urban and peri-urban areas. Participants living (partly) outside metropolitan areas point out that they have fewer chances to use sharing platforms, as they are less widespread in local contexts. In many instances, they refer to ride sharing, or to on-demand services, while few refer to Couchsurfing or home-sharing that can be used wherever an internet connection is available.

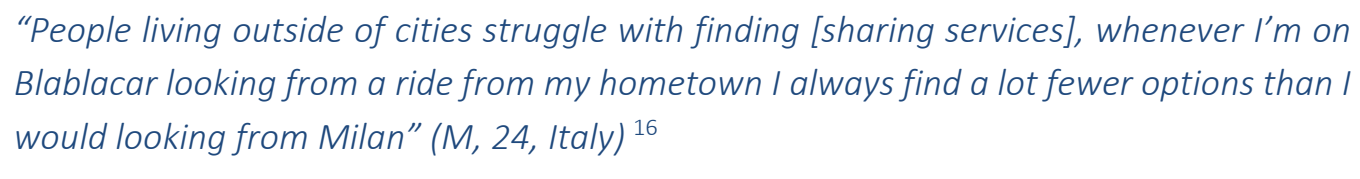

Lack of access to sharing services can also be due to users not owning the necessary devices (especially smartphones), means of identification, or payment methods (credit cards). However, very few participants referred to such obstacles as causes of non-participation. 
"(...) for example, I can only use Airbnb if I have a credit card. (...) I have to have a bank account, I have to be involved in this system. If you have that, you can use it, and you have to have a computer." (29, M, Switzerland) ${ }^{17}$

As indicated above, some participants reported to be only indirect users of the sharing economy, as they accompanied friends or family members who booked a service. A participant reported having no account on any platform at all due to privacy concerns. Yet, through friends, he still often used sharing economy services.

"I always count on someone else being registered there. When you use it as a group. Because I don't like to give away my data, because I just don't know what will happen to me in the future if I do. So it is not about today, but I think it could be very unpleasant if that data could impair my career prospects. So I hold back very much with digital transactions and sharing data and always hope that someone in the group has an account." (25, M, Germany) $)^{18}$

"Well, I haven't. It's my boyfriend that actually does it. I don't even have the app." ( $F, 30$, Norway)

Users-by-proxy participate in the sharing economy indirectly. They delegate the coordination of the ride- or home-sharing to others for various purposes such as trying to avoid providing too much data to a platform or website.

Far more frequently, focus group respondents highlighted how they act as proxy users, compensating for someone else's lack of literacy or familiarity. This occurs frequently in the context of generation gaps. Most participants found a difference in familiarity between their generation, grown up around the technology needed to participate in the sharing economy, and those of their parents or grandparents, who often lack familiarity and/or technical access. Sometimes, members of older generations delegate the access and management of sharing economy services to their Millennial relatives:

"I rented out a flat for my parents on Airbnb, you know, when they came visiting." ( $F, 35$, United Kingdom)

Respondents who are used to acting as proxy users reported frustration at older relatives who find even indirect participation too burdensome and end up favoring a traditional alternative to sharing economy services. 
"Yeah it is exactly the same for my parents. For example, my dad or my mom don't use Uber, they just take the taxis and I've been explaining to them, 'Okay, you have to take Uber. It's cheaper.' And they're just like, 'Okay, I don't know how this works and I don't trust the mechanism of putting my card on some app. I don't want to put my card.' So they just take the taxi and pay by cash." (M, 22, Norway)

\subsection{Outcomes of Participation}

Our analysis detailed three main outcomes of participation in the sharing economy: Economic outcomes, social motives, and authenticity.

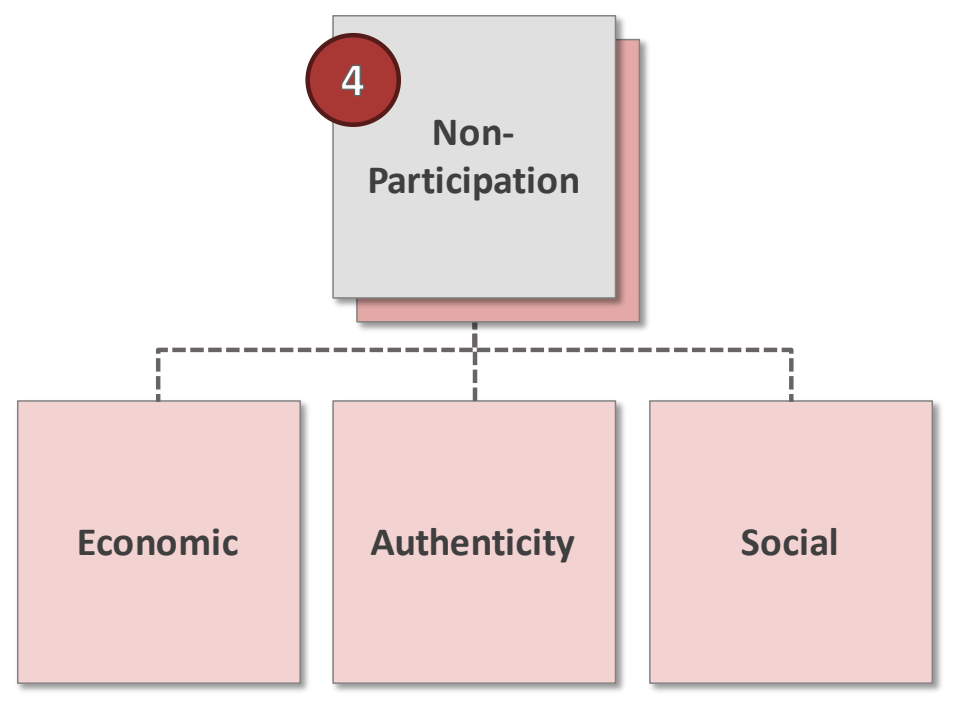

Figure 5: Code Structures for Participation Outcomes

Given that economic motives appear to be the most salient among Millennial participants of the sharing economy, individual-level outcomes also cluster around economic benefits, such as savings. Some respondents mentioned the participatory benefits of cheaper sharing services as more people are able to afford these services, for example when traveling.

\footnotetext{
"It might also be a good thing because we are talking about you know hotels and taxi drivers who are losing customers, but I think the overall customers are growing because it's cheaper. So a lot of people who can't afford a hotel room or you know they think, "Yeah I'm not going to pay that much money for a taxi driver", they just take an Uber and they just take an Airbnb. So there's a group below the group who normally goes, which now can rent a room or take an Uber instead of not doing it. So I think that overall population is bigger now, so that's a good thing." ( $F, 30$, Netherlands)
} 
The professionalization of sharing services is also seen as detrimental since one important noneconomic benefit of sharing services is the opportunity for social interactions and the sense of authenticity and reciprocity. Many Millennials enjoy the opportunity to interact with local hosts when abroad. The more professional sharing services become, the less distinguishable travel experiences become from traditional, non-sharing service experiences.

"I've been only twice to Airbnb and the first time it was in someone's house and it was very obvious that it was someone's house. The host lived there at the same time whereas the other time, it was a business, a full-time business for a person who worked in a company and they had lots and lots of flats that they had on Airbnb. I think part of me using Airbnb was to kind of get an authentic feel for that place when I went to visit. So living in like a stripped flat where there was like no personal feel, I might as well have used the hotel, although it's a lot cheaper obviously with Airbnb." (F, 30, Norway)

When discussing large sharing platforms, Millennials show quite ambivalent feelings about authenticity, weighing individual-level benefits and potential societal benefits against the emergence of dominant commercial providers and the commercialization of sharing.

"But in the case of Uber, I don't think it's part of the sharing economy. I just think it is a matter of, like, someone providing a service. Like, freelance autonomy, kind of like labor relations with Uber and I mean, the idea of this person sharing their car is bullshit because this person's working full-time." (F, 33, United Kingdom)

"How is that at Airbnb? When I rent my apartment there and always on a grand scale and so on... People have already complained, for example in (German city), or I know an actual example, in (Dutch city) the people just enrich themselves and there is no sharing spirit at all, just 'I have something and you give me money for it'. This has little to do with the idea of sharing." (F, 24, Germany) ${ }^{19}$

At the same time, it should be noted that respondents reported relatively few benefits from social interactions. This becomes clear with regard to the fact that consumers and providers appear to only very rarely transact more than once, which prevents the creation of social bonds through social interaction. Accordingly, interactions facilitated through sharing services tend to be quite superficial and transient. 
"You assume that everything is temporary so you are ok with sharing a piece of your life, make some small talk... but you expect it to be over soon." (M, 26, Italy $)^{20}$

"It's a bit like when you're riding on a train and some old lady wants to chat, of course you do it, but it's not like you become best friends afterwards." (F, 25, Italy) ${ }^{21}$

When asked to think of potential outcomes for providers of the sharing economy, respondents, once again, mainly focus on economic benefits (additional income). They also expressed a certain mistrust for large, professional sharing services. Participants weighed both the effect on established services as well as possibly questionable working conditions against the income available through sharing. Most participants embraced the idea that sharing services should be regulated so as to provide a fair treatment of workers.

"It's good for a host of Airbnb but it's really bad for the tourist industry in Amsterdam. Hotels are getting less full or Amsterdam is getting more crowded with tourism because they can stay everywhere for much less money than they could stay before." ( $F, 21$, Netherlands)

"But I think there must already be regulations for this. Just for people who do this professionally. And that there are also higher penalties, deterrents et cetera when talking about regulation. Because all these things also have disadvantages... but for private individuals who really only offer it... It is always difficult to find the right degrees, of course, but for private individuals I am now not in favor of more regulations, because it bureaucratizes this community..., this sharing idea." (M, 24, Germany) ${ }^{22}$

Some respondents also reflect on how a more heavily regulated sharing economy may end up increasing the prices and excluding consumers.

"I think just in general, I think as a consumer - not seeing like the outside picture of all of the regulations and that like - if they begin to be taxed and then, obviously, the price would go up and, as a consumer, we wouldn't like that." (M, 20, Norway)

Participants reflected very little on societal outcomes of their sharing behavior. Here, outcomes again mirrored the most prevalent motives for sharing. Just as discussants only superficially discussed societal motives for sharing, mostly only when prompted, notions such as economic change, sustainability, or resource efficiency play a limited role in their reflections of key outcomes. 
"Of course, sustainability isn't just tied to the sharing economy, but I think that the sharing economy can be sustainable in several ways, that it has three aspects of sustainability: financially less costly, using less resources, and facilitating social interaction. It doesn't have to happen and it can have side effects, but ideally, that's what if can offer." (24, M, Switzerland) ${ }^{23}$ 


\section{Privacy}

Millennial consumers have rather ambiguous attitudes towards privacy when it comes to the sharing economy. Respondents reported, on average, relatively high levels of concern regarding the potential loss of control over their data. However, they often also found themselves automatically providing such data, as means of paying for a service with personal data as currency. While some respondents thoroughly reflected on what data they provided in exchange for which service, others felt rather resigned or even cynical about the exchange, not quite agreeing with it but also not willing to give up the services. This appeared particularly true for younger respondents.

Four main themes emerged from the analysis of privacy in the sharing economy. They consist of the attitudes and practices of information sharing, privacy concerns, behaviors and management of privacy, and the issue of trust. The following sections will provide an overview on each.

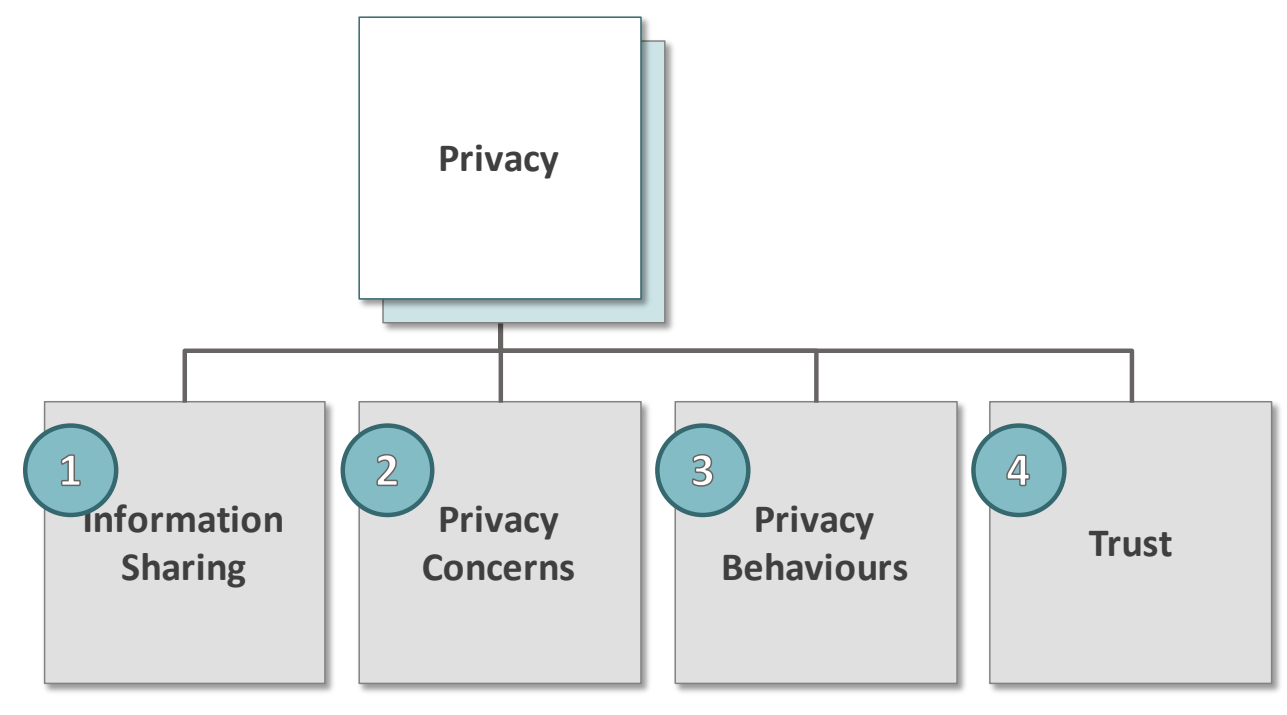

Figure 6: Privacy - Main Code Structure

Interestingly, privacy within the sharing economy seems to be a rather multifaceted concept for Millennial consumers. In fact, consumers share personal information with both platforms and other users, mostly the providers of services. Furthermore, this information consists not exclusively of personal data, but also of the object of conversations, be it online or through face-to-face interactions.

Respondents within our focus groups appeared overall to be significantly more concerned about privacy invasions resulting from contact with other peers, than about possible violations by sharing platforms. Interestingly, the risk of breach of 'physical boundaries' was perceived to be higher than risks related to online stalking or fraud.

Our sample of Millennial consumers reported different strategies to secure services while reducing perceived privacy risks. Impression Management, either through user profiles or direct messages, 
was used by respondents in order to appear more attractive to a specific provider, thereby securing the service they want. Impression Management was also employed offline, to influence positive reviews which can in turn guarantee future access. Risk reduction strategies include paying attention to elements such as a provider's word usage or what is included in their pictures. Millennial consumers appear to rather heavily rely on $3^{\text {rd }}$ party reviews, while critically reflecting on their quality. Reviews appear to also play a very important role into how Millennial consumers establish trust, toward both peers within the sharing economy and sharing platforms. Numerous and positive reviews, in the eyes of respondents, reward providers who are trustworthy. At the same time, even a positive review can provide details that allow consumers to make a more informed and safer decision. While a few respondents highlighted remarkably little trust in sharing platforms, the majority reported that the review system contributes to a high perceived trustworthiness of the whole system. More structured review mechanisms, such as the one from Airbnb, are perceived as increasing consumers' safety, and therefore the platform's trustworthiness.

\subsection{Information Sharing}

Through the coding process, four main attitudes towards information sharing were identified in the context of the sharing economy: Inevitability, optimism, negotiation, and cynicism.

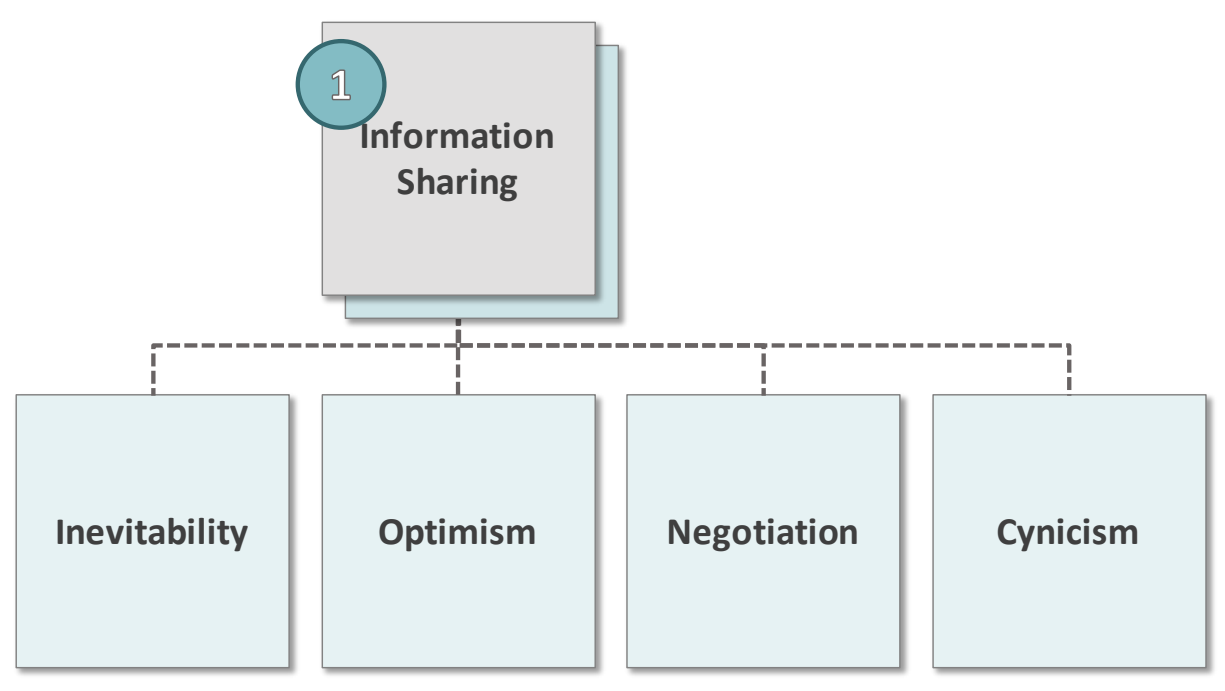

Figure 7: Code Structure for Information Sharing

One of the most prominent themes emerging from focus group respondents, whether consumers or providers within the sharing economy, is how their evaluation of privacy-related concerns is formulated as coupled to the perceived benefits associated with their participation. This mechanism is widely known as the privacy calculus, identified, for example, as taking place within online Social Network interaction. However, within the sharing economy, a slightly different benefit is associated 
with the sharing of private data and goods, namely the access to the platforms and the services and advantages related. While the majority of focus group participants reported at least some awareness over the exchange happening between data sharing and access to the platform, their perceptions over the fairness of this exchange, and over their ability to exert some type of control, varied greatly.

Respondents with an inevitability attitude highlighted how the provision of private data has become almost an obvious contribution in order to access not only the sharing economy, but also most services within society. While respondents do not appear to have a pessimistic view over whether the exchange might be worthy of their data, they also do not perceive to have much control over the choice to provide such data.

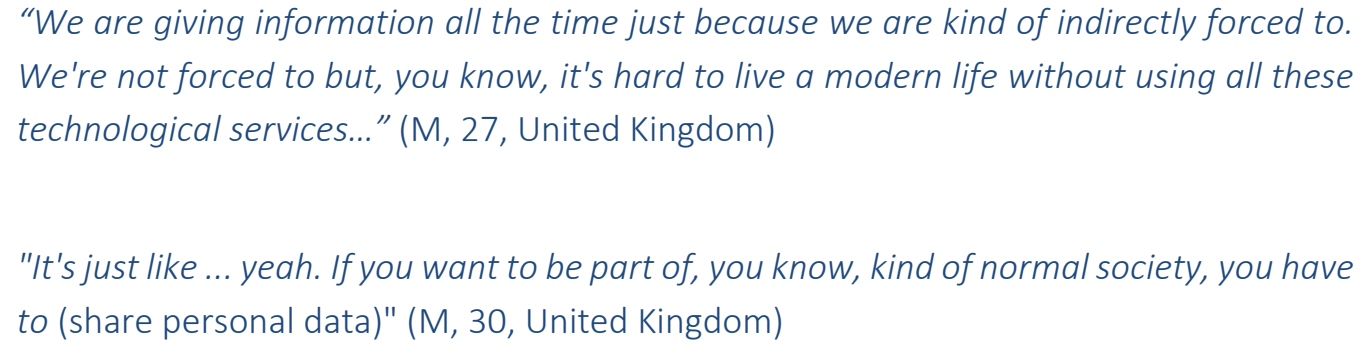

Respondents' optimism attitudes are rather positive on both the fairness of their data exchange and their degree of control over it. Some of the respondents' answers draw comparisons between social network sites and sharing economy platforms, highlighting how different values could be assigned to their data, depending on what service it is exchanged for. Other respondents stress how their provision of their data could contribute to improving the sharing economy services.

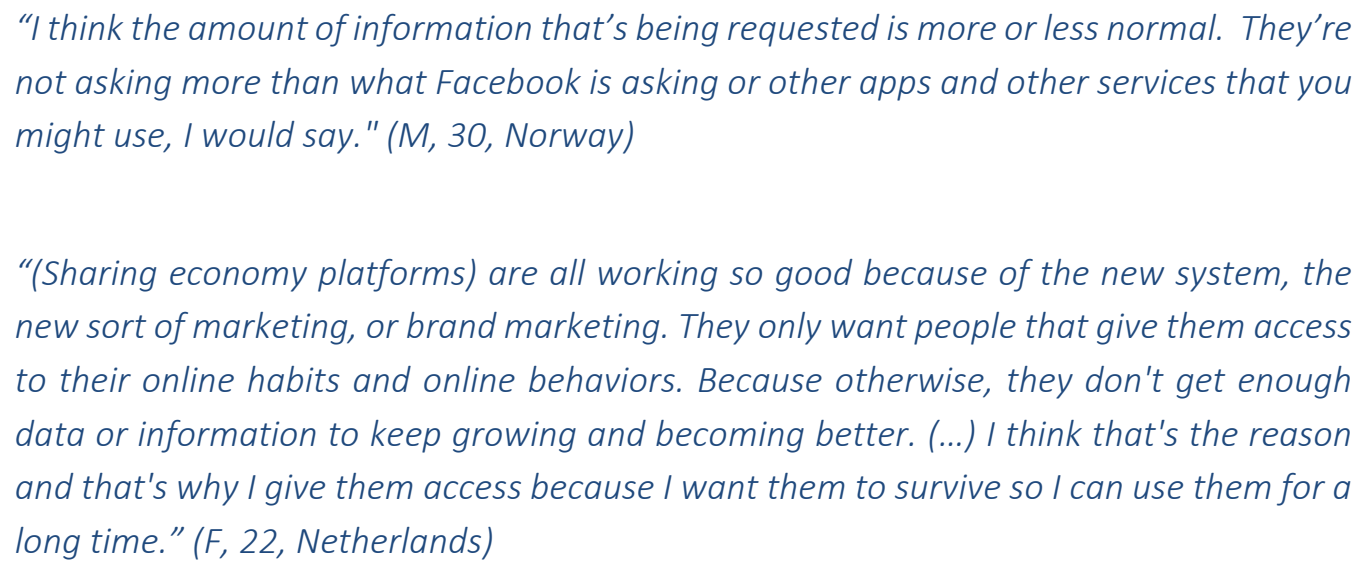

Not all respondents stressed optimistic attitudes towards their data provision in exchange for access to the service. Responses coded under the category negotiation are characterized by an attempt by users to only provide their data when they feel like the exchange is worth the risks inherently 
included. This denotes some insecurity around the fairness of the data exchange, but also around how respondents feel like they have control over how much data they provide and are therefore better able to participate in a way that feels adequate to their needs.

"So with respect to the privacy, I think there's a natural selection and as I said, you can provide as little as possible. That means you might not get accepted everywhere or by anyone. I guess that's up to you that if that's your choice and that's what your kind of preferences are. I don't think you should be obligated to provide more information by default just to be able to partake in the service." ( $M, 30$, Norway)

"As for me (...) I am still rather positive about (the sharing economy), but also I know how much data I want to give up. At least at face value, because nobody ever really knows what happens in the background. I just want to use (the platform) and give little (data) back." (M, 28, Switzerland) ${ }^{24}$

One group of responses stressed pessimistic views on both the fairness of data exchange and the respondents' degree of control over data sharing. A key element to this cynicism attitude is the relative apathy respondents seem to have towards both their participation and their provision of data, as though the first would be substantially inevitable and the latter impossible to control. Some responses coded under this attitude highlighted a generalized feeling of incapacity (or lack of interest) in attempting to protect their data while interacting online, which extends to participation in the sharing economy.

"Actually I'm slightly annoyed by all these privacy control options, because in the end it's not real, and as far as I'm concerned... in fact it seems like an oxymoron to talk about privacy." (M, 25, Italy $)^{25}$

"For me (providing location-based information) ... it's not really an important thing. Because I'm not a spy... Because anyone could track me... I don't think it has any importance." (F, 33, United Kingdom)

"We're kind of all born in digital age. We know that everything that is put publicly is you know, like basically you going out and screaming into a mid-size city."( $M, 20$, Norway) 


\subsection{Privacy Concerns}

The privacy concerns of users of sharing services can be grouped around issues of data, boundaries, peers, and platforms.

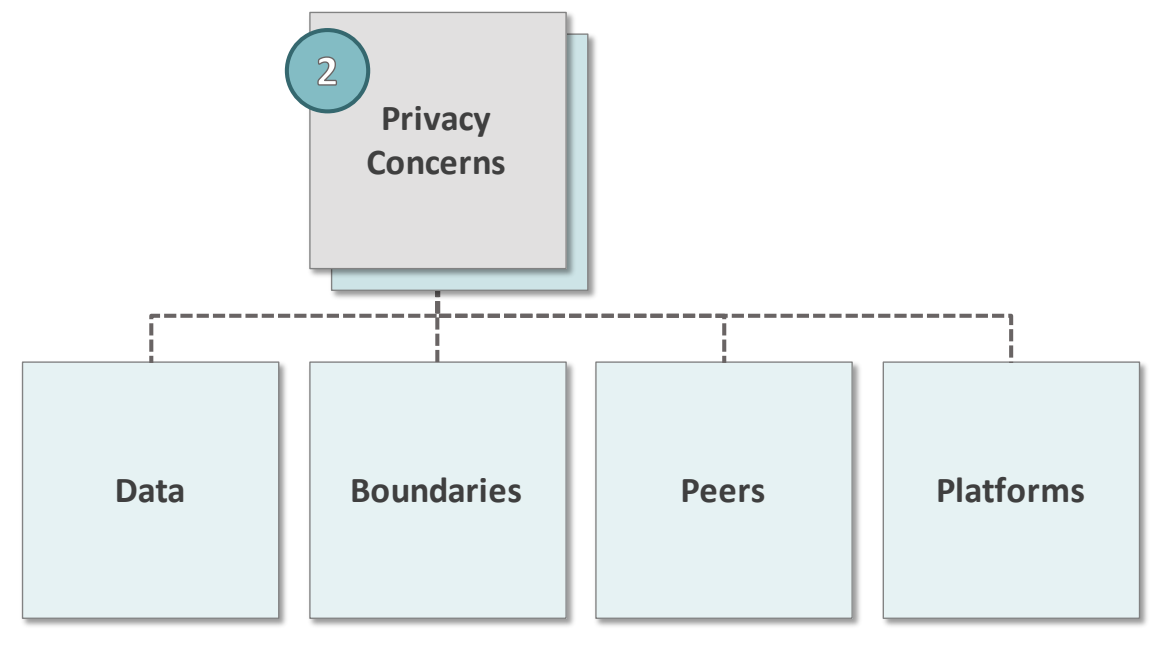

Figure 8: Code Structure for Privacy Concerns

The participation of consumers in the sharing economy presumes the establishment of a relationship with both a platform, which secures access to a service, and to a peer provider, who provides the service. Consequently, the privacy-related concerns of consumers appear relatively multi-faceted, as they appear to negotiate their level of sharing differently depending on what they share, and whom they share it with. Respondents' data from the focus groups was coded so as to highlight these existing differences.

Considering what is to be shared, and not dissimilarly from users of other peer-based platforms such as social network sites, respondents seem to be concerned about what happens to the data they hand out to sharing economy platforms. In particular, they stress their fears surrounding potential risks coming from data aggregation. In fact, as platforms incentivize log-ins through Social Networking Sites (such as Facebook), or depend on location-based data, consumers grow concerned about how precise their behavioral tracking might be becoming.

"Yes sure, you could manage it all in your Privacy Setting, but in the end, what happens in the background? Sure they have to adhere to laws, but you (user) cannot really check that they do." (F, 23, Germany) ${ }^{26}$

"Come to think of it like you know, like how easy it is to kind of map your preferences if you get to know your Uber data, you get your Airbnb data. We add that with some Facebook data, you can get, like -- that's the marketing person's dream, right where basically all your preferences are revealed." (M, 31, Norway) 
Since the nature of participation within the sharing economy presumes that consumers use goods, spaces and services shared by other peers, further privacy concerns arise about physical boundaries ${ }^{6}$ with providers and with their shared goods. Interestingly, while data-related concerns do not appear to stop users from participating in the sharing economy, focus group respondents highlighted how their concerns around sharing private goods actively prevented them from taking a provider role on the platform.

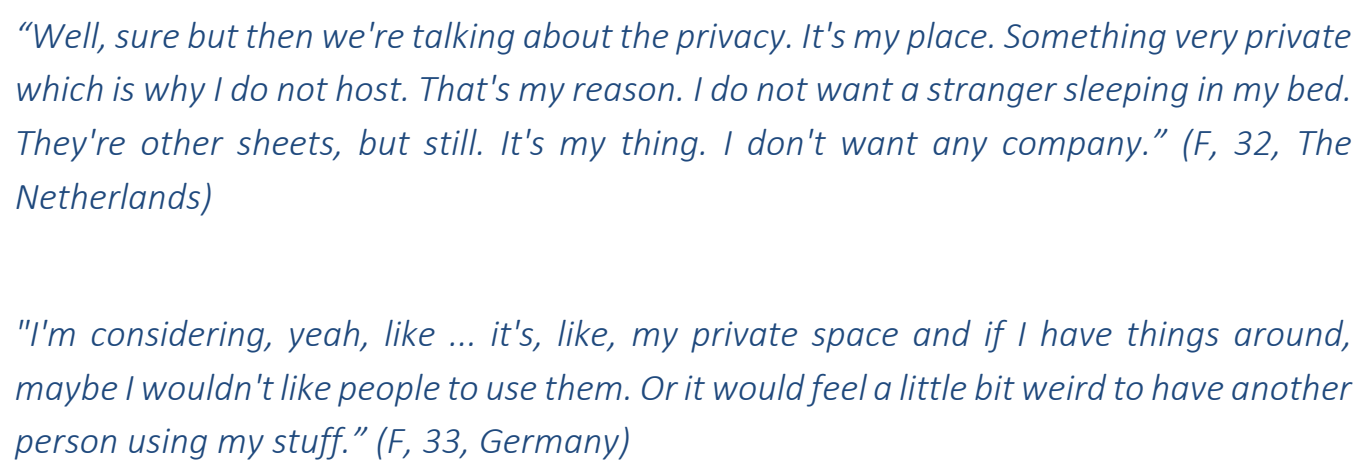

An interesting sub-theme emerging from respondents' concerns over a physical privacy invasion, whether received or in a hypothetical setting where they'd be providing a service, is their consideration of the inherent privacy of different sharable goods and spaces. Respondents expressed different opinions on how private an apartment, or a car, could be considered, and therefore reflected on how differently risky it could be to share them. They also elaborated on the different boundaries consumers and providers might have to negotiate.

"I'm not sure if that applies as much with other services or products like Uber. I'm not sure if I would consider that's like a potential privacy violation in any way or like something possible there, because you're in the car with the person, but I don't know if you keep that many private things in the car I guess." (F, 26, Norway)

"I would probably still make a difference between the private sphere of a car and Airbnb. Because I find: if I now rent an apartment it is more of a private sphere than if I ride in a car, which I might still have rented. And with Airbnb, there is so much more to be negotiated: when can I use the kitchen, do I have to talk to them for a long time, or can I maybe go upstairs..." (M, 24, Germany) ${ }^{27}$

\footnotetext{
${ }^{6}$ See also: Chapter 6.1.
} 
Another dimension on which privacy concerns seem to differentiate for consumers within the sharing economy is with whom data is shared with. Once again, respondents seem to perceive the fears emerging from data being shared with peers as substantially different from those surrounding institutions. Judging from some from their responses, focus group participants seemed to express concrete fears surrounding what other users could do with their data.

"I feel a bit uncomfortable that anyone can Google me and find my picture. As I said, I feel uncomfortable. I don't really have a good reason not to but I just, like, feel that it's not good. The other thing is that people can actually ... I really don't know how they can use the information." (M, 30, United Kingdom)

Other users specifically focused on dangers that more indirectly could derive from peer access to private data, such as the risk of wrongful damage to one's property or private person.

"And I actually think that this has some sort of -- there is a creepy Uber driver who wants to -- I don't know -- to use you in some way. I don't mean sexual abuse, but right? But I don't know, even just to scare you or anything. There is no way you sort of can prevent that, but those cases are minimal." (M, 30, Norway)

Focus group participants also reported significant concerns surrounding the use of private data they shared with platforms. Potential (mis)use of private data from institutions seemed to generate in consumers a generic discomfort rather than specific fears, deriving from what they perceive as a low degree of control. Some participants hint at how regulation could help them feel more at ease with sharing data.

"For me it's a not huge worry that I go around worrying about all the time. But I feel that people know too little about what their data is used for. And also I think that -- because the difference with the smart corporations and not so smart corporations is that they know how to use the data, and know how to influence you through using your data." (M, 20, Norway)

"I think some of the regulations, most of the regulations also focus on kind of the data part that we were kind of discussing because if now, the Googles and the FaceBooks are being regulated by Europe (...) then of course, the shared economy should kind of brought in that gambit because why would I kind of trust an Uber or an Airbnb with so much data that I am putting and why would I allow them to track where I am going and to set back 
and sell that to any other third party. That's one of the concerns, definitely, that I would have." ( $M, 35$, Netherlands)

\subsection{Privacy Behavior}

Aside from elaborating on their privacy concerns, focus groups respondents signaled different types of behaviors they put in place to participate in the sharing economy, disclosing the type and amount of information they feel comfortable with. These behaviors were coded under two main categories: impression management, i.e., the information users strategically disclose about themselves, and risk reduction, i.e., the strategies users put in place to minimize risks related to their interaction with peers.

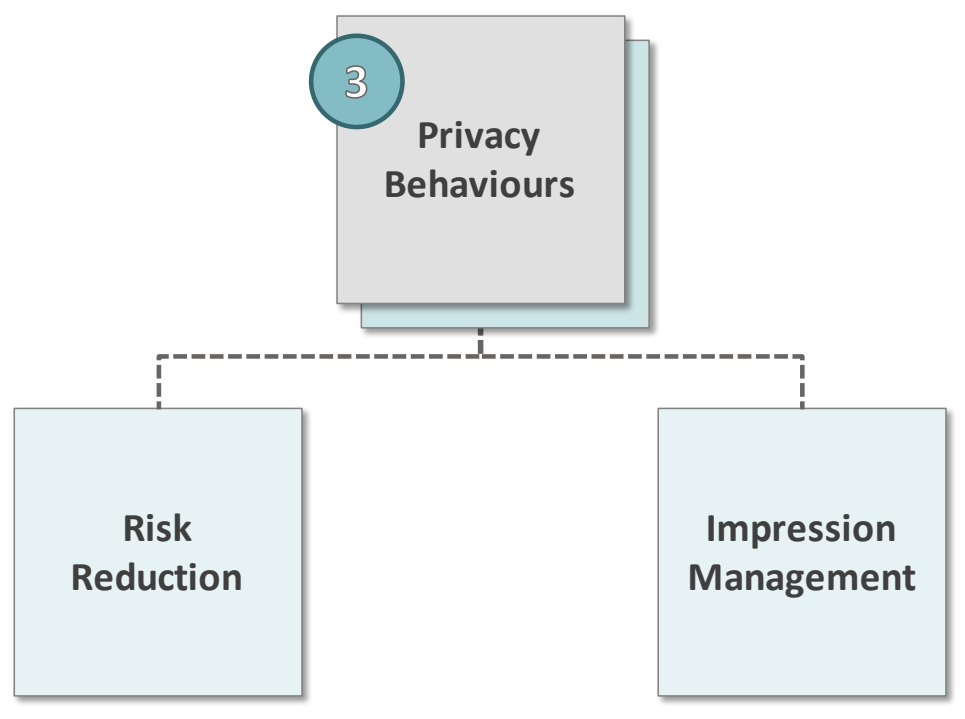

Figure 9: Code Structure for Privacy Behaviors

Impression management strategies take place on multiple levels, as sharing economy consumers interact with providers both online and offline, as well as both privately and publicly. Respondents seemed to subtly differentiate the amount and type of information they share in each different context.

As platform profiles represent the way consumers of the sharing economy introduce themselves to providers, respondents report finding their choice of what information to share as crucial to guarantee both access to the platform, and a "match" with the wished-for provider/good. However, the publicness of information available on profiles also raises concerns, which respondents address by selecting the information they choose to share.

"(You should share) ...something you like. Something, you know, your more personal attitude like what's your aim. To discover the city? To go for a conference like a business 
meeting or something perhaps like that? Perhaps you can get a host, a person that's not just treating you as a customer when you have this attitude" ( $F, 28$, Netherlands)

"Publicly, now that I start thinking of, "Who might see this? Who I wouldn't want to share this information with?" (F, 25, Norway)

Not all information exchanged between consumers and providers of the sharing economy happens through public profiles. A significant part of information is shared through private channels, such as direct messages, e-mail or SMS. Respondents seemed to perceive these as "safer" channels of communication, and therefore adequate to share the type of details they would not feel comfortable sharing on a public profile. Information shared on a private channel can also be a strategic asset towards accessing a wished-for service, such as securing a specific property on Airbnb.

"I only do it (share private information), when I book. In the email I write a little bit about myself and about what I will do in the city. But never on my profile." $\left(F, 23\right.$, Germany) ${ }^{28}$

"The same things I would put on the profile, preferences or whatever, hobbies, you can find that you can also see on my social media. I don't have any issues with that. Although I would give more details, if necessary, if asked for in private." (F, 26, Norway)

Focus group respondents also elaborated on the Impression Management they carry out offline, when interacting with providers face-to-face. Interestingly, even after having secured access to a service, consumers feel like they are pressured into strategizing how they interact, performing a degree of sociability some respondents find uncomfortable ${ }^{7}$.

"Especially when you're together for a relatively long amount of time, it can be - well a little embarrassing. Of course, you could also not say anything if someone keeps asking you questions. But it's not like you can simply NOT answer, that's just not ok. So you're somehow forced to hold a dialogue, in a way." (F, 24, Germany $)^{29}$

An alternative set of behaviors consumers put in place while navigating privacy on sharing economy platforms is what was coded as Risk Reduction, encompassing respondents' strategies to ensure the reliability of their chosen provider with their private data and, eventually, belongings and selves.

As Risk Reduction strategies involve the scanning and interpretation of cues among available provider information, respondents stress the importance of how profiles and personal communications are

\footnotetext{
${ }^{7}$ See also: Chapter 6.1.
} 
constructed. Respondents claimed to pay specific attention to words, expressing how, in a reducedcue context like a profile on a platform, they could help exclude providers perceived as rude or untrustworthy.

"I wouldn't be prejudiced against a reply that shows poor English. Although of course that signals they're a foreigner, but then again, so am I, and to them I'm also a foreigner. So I don't have anything against that per se. But I wouldn't -- of course language is an important cue to, "What kind of person you're dealing with? Is it a person that's trying to be polite and being respectful?" (F, 26, Norway)

"I believe I would pay attention to how they write, not so much if it's correct or not, but rather if someone, for example, overall sounds polite, or writes nicely or not so nicely. There are differences even in that." (F, 24, Germany) ${ }^{30}$

When trying to exclude providers perceived as unsafe, respondents also highlighted the importance of pictures. They reported to pay attention not just to photos depicting the good or property being shared, but also to profile pictures of providers, scanning them for cues of possible undesirable behaviors.

"I don't really care if it's a family, but if the host has a profile picture which I think looks like someone I could trust and I read the reviews and they're all very positive, yeah." (F, 30, Netherlands)

"So I'm somewhat untrusting in general, but I tend to look at a person for the way they present themselves even in a picture, say, if they wear a shirt rather than a tshirt with holes...l'd consider them more trustworthy than someone who, say, is in a picture driving while drinking a beer. I don't know. Then of course they can also have reviews, but still..." $(F, 23, \text { Italy })^{31}$

Consumers to the sharing economy seem to assign reviews a primary role in risk reduction strategies. Respondents highlighted how the neutrality of $3^{\text {rd }}$ party reviews increases the reliability of information involved and how the content of reviews completes and helps interpret rating systems. We discuss the role of reviews in establishing trust in the following chapter.

"Four stars for me usually a safe indication, because you'll always have some people ... I do this with all products by the way, but it's always from people who put in one star or something, but four stars is, usually it's a high. It's high anyway and there have been 
people put in five probably, so four would be perfect for me. Three is risky, but four or five is perfect." ( $M, 25$, Netherlands)

"I also pay a lot of attention to the comments from other users. Often, they really describe a person for how she is. If she was nice or not, and one would normally put more trust in someone neutral rather than someone who's advertising, someone who writes about oneself. Nobody would describe oneself as: 'I'm unpleasant'." (F, 23, Germany) ${ }^{32}$

\subsection{Privacy and Trust}

The topic of trust can be divided into issues concerning trust towards peers and trust towards platforms.

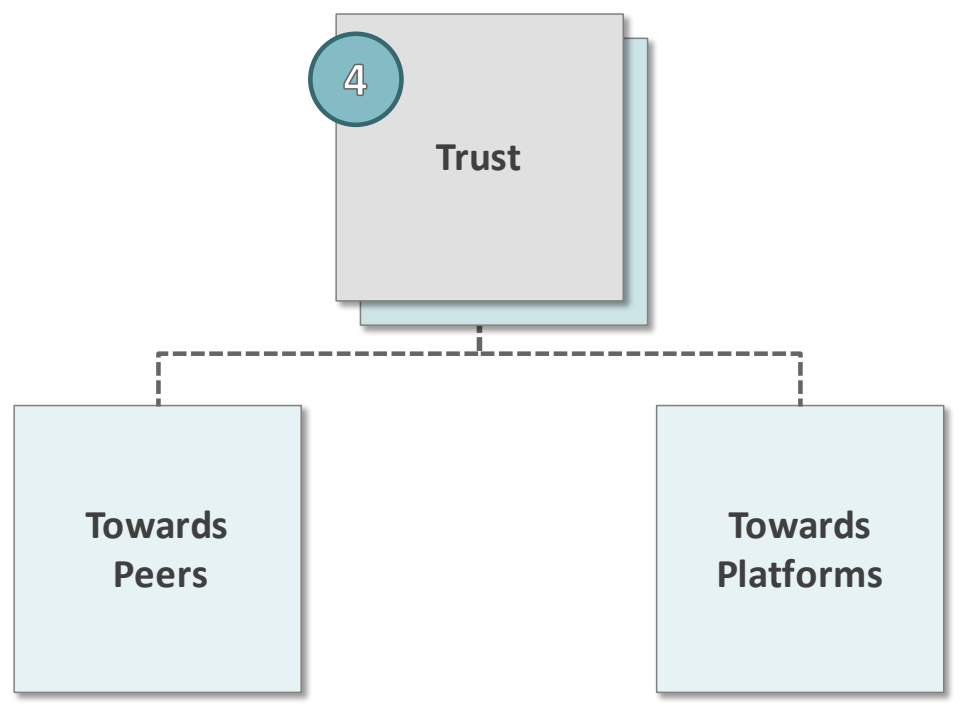

Figure 10: Code Structure for Trust

The perception of privacy concerns, both within and outside of the sharing economy, seems to be largely connected to the perceived level of trust, both in other peers and in the platforms. Trust in a platform might lead users to feel safer while disclosing private information. A trustworthy provider might provide a more attractive service and mitigate a consumer's concerns.

According to our respondents, trust within the sharing economy is conveyed through similar instruments for both platforms and peers, in particular through the review/rating system. For Millennial consumers of the sharing economy, an efficient review system allows them to both make an informed decision about an individual provider and trust the functioning of an entire platform. Accordingly, we can observe spill over effects between trust in platforms and trust in peers. 
Some respondents highlighted the role that reviews have in establishing trust towards peers. Interestingly, they also mentioned how third-party reviews allow them to be perceived as more trustworthy, thereby increasing their opportunities of being chosen by the provider they want.

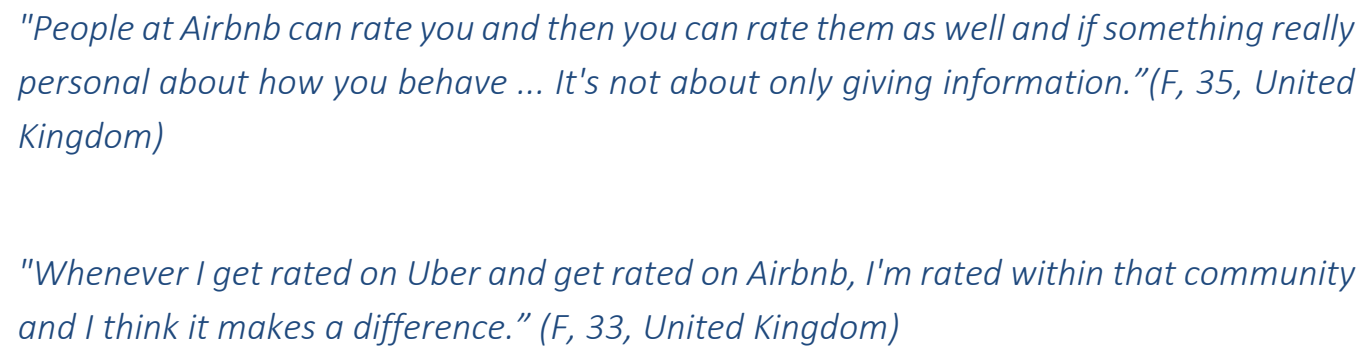

Other respondents highlighted how, additionally to third-party reviews, they found the opportunity of direct communications with providers an important tool to establish their trustworthiness.

"Yeah, except for when you just had a conversation with them online and they seem trustworthy then, you feel safe about it. If not then it's just a risky take." $(F, 29$, Netherlands)

A well-functioning feedback system seems to provide Millennial consumers not just with a more trusting attitude towards their peers, but also with more trust towards sharing platforms. To a certain extent, unsurprisingly, it appears that instruments aimed at making peer-to-peer interactions safer and more reliable might also improve customers' perception of the trustworthiness of platforms.

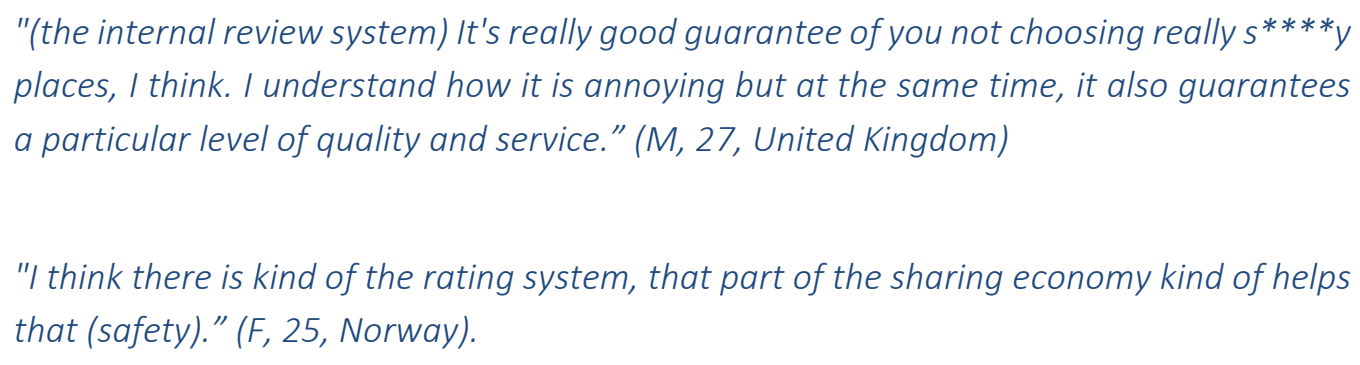

Especially in the context of privacy, it is important to highlight that, for some of our respondents, feedback systems are not sufficient to overcome concerns around their data. 
"It's about actually, like, I don't know. Like, it feels like constant surveillance, right? Like, you have to introduce yourself and tell what you're doing there. (...) This information can be public in form of ratings." (F, 35, United Kingdom)

"Basically, I go back to what I said before. Theoretically, when we debate here, I don't trust them. But then again, what would really happen, you know? If they do something really bad, people are going to react and then yeah, okay. In a real conversation, I would say no, never, I don't trust these guys." (M, 30, United Kingdom) 


\section{Power}

Among European Millennials, we found conflicting attitudes towards the power dynamics inherent within the sharing economy. In general, respondents demonstrated a transactional approach to using sharing services, driven by economic motives. However, the professionalization of sharing platforms was nevertheless considered an unwelcome advancement and a step away from authentic sharing experiences.

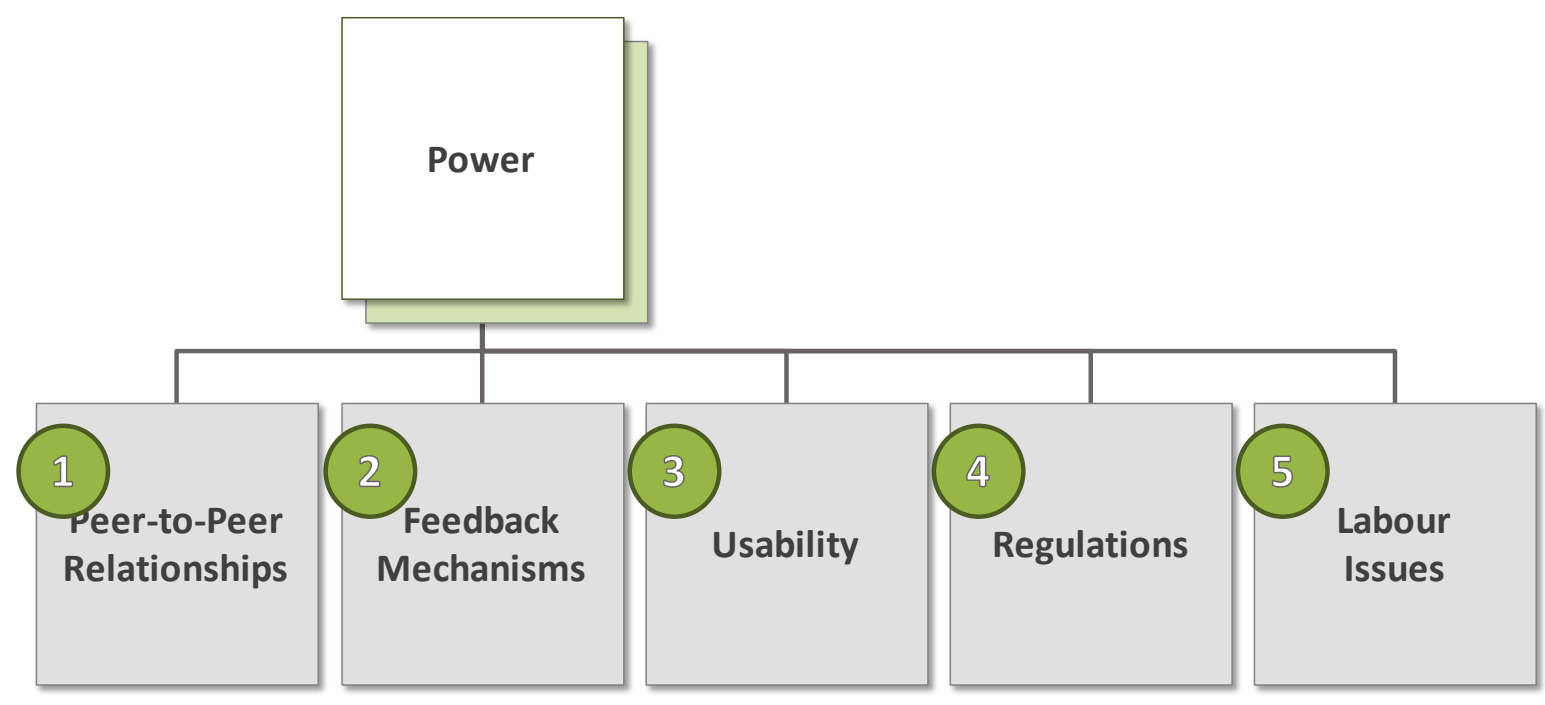

Figure 11: Power - Main Code Structure

While respondents were overall positive towards the sharing economy as a commercial option, their self-interest as consumers was reflected in attitudes towards inter-personal relationships, feedback reciprocity, taxation, labor issues, and regulation. For many participants, social elements such as the need for emotional regulation were considered performative and thus a disincentive against participation. The informal peer-to-peer nature of the sharing economy also raised a number of issues. For instance, while some respondents highlighted the potential for discrimination as a prominent concern, others framed discrimination as merely a factor of freedom of choice among providers, which both could not be controlled and should not be controlled.

Interestingly, the role of bilateral rating mechanisms played an important role in the experience of the sharing economy and respondents demonstrated relatively sophisticated views on the topic. Often ratings were discussed critically and, for some, were approached somewhat strategically to maximize their own opportunities. An awareness of the reciprocal nature of ratings altered some behavior, nudging them towards giving more positive or neutral reviews. Ratings were perceived as being unfair, being based on a mixture of both legitimate and non-legitimate factors. Attitudes varied over whether it was the system which needed to be changed, or whether users needed to be better informed about feedback criteria. 
An important dynamic for our Millennial consumers was the relationships developed and experienced with the sharing economy platform itself. Some respondents praised sharing economy services for their transparency and technological affordances, placed in contrast to traditional services such as taxis or hotels. However, there was a persistent thread of uncertainty around not only the platforms, but also other users. It was clear that, while trust had been somewhat established, there was room for improvement. For instance, respondents were unclear over who would be responsible if guests stole or damaged property in a home-sharing situation.

Regulatory and labor concerns were raised and debated. While some respondents were concerned about the questionable legal status of sharing platforms, an interesting attitude that emerged was that respondents approached issues of regulation and taxation from a position of self-interest. For instance, while higher taxation on sharing economy services was viewed as desirable, consumers didn't want that to result in price increases for themselves.

Frequently, respondents had strong partisan opinions about the reputation and benefits of a certain platform over another. It was apparent that they had an awareness of debates in the media, but some indicated a relatively uncritical acceptance of platform narratives on topics of regulation and platforms' business models. The predominant viewpoint was that providers were self-employed or freelancing, rather than employees of the platform. Interestingly, respondents who were providers themselves shared this evaluation, self-identifying as non-employees.

\subsection{Peer-to-Peer Relationships}

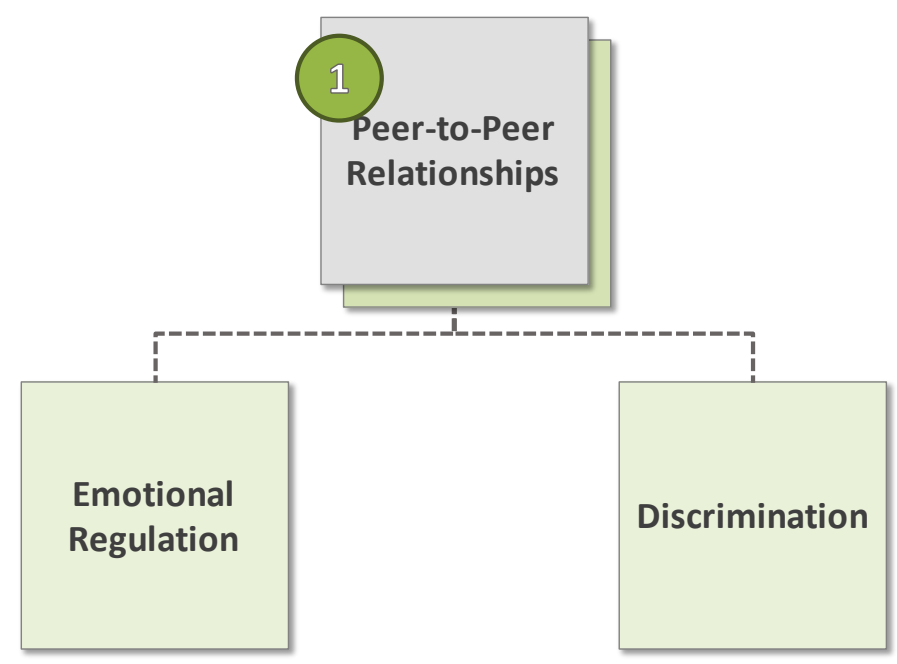

Figure 12: Code Structure for Peer-to-Peer Relationships

Focus group respondents signaled their pre-occupation with the unique nature of the peer-to-peer relationship. 
One of the prominent themes to emerge was an ongoing concern among both providers and consumers about the emotional and attitudinal requirements of a sharing transaction, with variations of expectation based on context and sharing modality. We coded these requirements as emotional regulation. While certain sectors of the sharing economy are relatively hands-off, such as financesharing, other sectors involve a significant value-adding service layer. In transactions with such a 'service' element, providers are put in the position of service providers, which mirror pre-existing service roles.

Accordingly, respondents expected providers to perform socially conforming emotional regulation, in the form of socializing, entertainment, emotional comforting, or small talk. This expectation was not viewed as an exceptional requirement, but as an expected part of the transaction, with limited reflection on whether it was acceptable to be so demanding of their 'peers'.

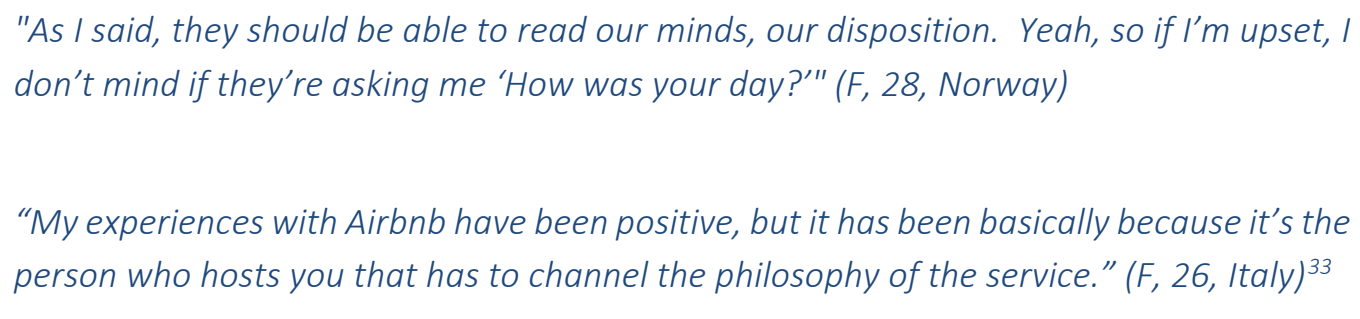

However, as a counterbalance, some respondents displayed a pessimistic attitude towards provider sociality, viewing it as an unwelcome element of what they perceived as a purely financial transaction.

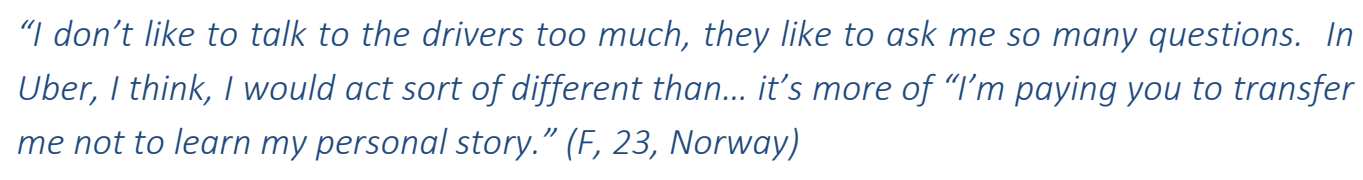

Complementary to such discussions, focus group respondents who had previously experienced the provider side expressed their resignation towards the emotional and attitudinal requirements of the sharing economy. It was emphasized that this was often a very performative activity, where the emotions displayed were not reflective of the actual attitudes. Respondents further noted that the expectation for sociability acted as a burden.

"And then there is this, that I have to entertain him during the ride, that I have to talk constantly with him. And that's really mostly very interesting and cool, but somehow you have to be in the mood for it. Sometimes, you drive back on a Sunday and think: 'Actually, I'm really not in the mood to talk with anyone'." (F, 23, Germany) $)^{34}$ 
Consumers reflected on the bilateral nature of emotional expectations, indicating that they also felt obliged to alter their own behaviors in line with socially conforming expectations. This was largely framed as a negative pressure and, for some respondents, strongly disincentivized their use of such services. Interestingly, and in line with ongoing research into emotional labor, awareness and discussion of the emotional requirements of sharing transaction arose as a gendered concern which was raised predominantly by our female respondents.

"I think I kind of expect them to be nice and I think they also expect us to be nice.....Yeah. I mean -- in sharing your comment there, there is this expectation of reciprocity, Oh, you're being nice. I have to be nice. This is horrible." (F, 25, Norway)

"What I find really annoying with Airbnb is that you have to be nice with people. I know it sounds horrible but I don't know. I guess I don't really enjoy small talk and when I go somewhere, it's just because I just want to be by myself or whatever. Then you have to ... obviously, you're going to someone else's house and you have to be nice as well." (F, 33, United Kingdom)

"So, for example, for me, I really prefer to take the train over BlaBlaCar or Mitfahrgelegenheit because I know that I can do my things and have my quiet and I don't have to make small talk for four hours. I don't dislike human interaction or anything but I find it really exhausting if you don't get along with the person and sometimes you are just tired when you sit in a car." ( $F, 24$, Germany $)^{35}$

The nature of the sharing economy as a peer-to-peer phenomenon requires the allocation and selection of sharing partners, namely those who you share with. However, an element of this selection process which was raised as a predominant concern among respondents was how it could swiftly transition into a mechanism of discrimination. Some respondents were quick to question the nature of discrimination preventions on sharing economy services, while also elaborating on potential solutions. However, respondents expressed two main conflicting standpoints with regard to discrimination.

Firstly, some respondents, who framed the boundaries of sharing transactions as being merely a commercial activity, discussed discrimination as a negative which was to be avoided and prevented in all circumstances. Such respondents held sharing economy platforms to the same standards, in terms of discrimination prevention, as traditional services such as taxis and hotels. In particular, some respondents noted that the platform architectures and business modalities of sharing economy companies reduced the potential to notice and prevent discrimination. 
"Technically, it's a business. You're making money off it. You have to be held to certain standards, that are, in my opinion, world-wide standards. You can't just discriminate based on race or religion." ( $M, 20$, Netherlands)

"There is like systemic discrimination when it's a bunch of individuals who are making these decisions who are not really -- we can't really be -- how do you say it, held accountable to the same extent as big companies. It's much easier for us or for me to say "I don't really like black guys, I'll accept the white guys instead." (M, 30, Norway)

The second viewpoint, with respondents taking a counter-position, framed discrimination on sharing platforms as merely a factor of freedom of choice among providers, which could not be controlled and should not be controlled. Given the peer-to-peer nature of services, and the fact that providers share their personal possessions, some respondents thought that users had the right to choose who they shared with, even if it could be perceived as discriminatory.

"I'm like, seriously people? It's my house. If I don't want to book these people, then I don't want to book these people. They should understand. I understand people can say no. It's normal." (F, N/A, Netherlands)

"So we basically think about, "Can we" the practical side of can we even do that? Can we impose it? But also should we? Right? You could say or you could argue that it infringes on the people's own liberty and freedom, right? Of their own personal space and everything." (F, 26, Norway) 


\subsection{Feedback Mechanisms}

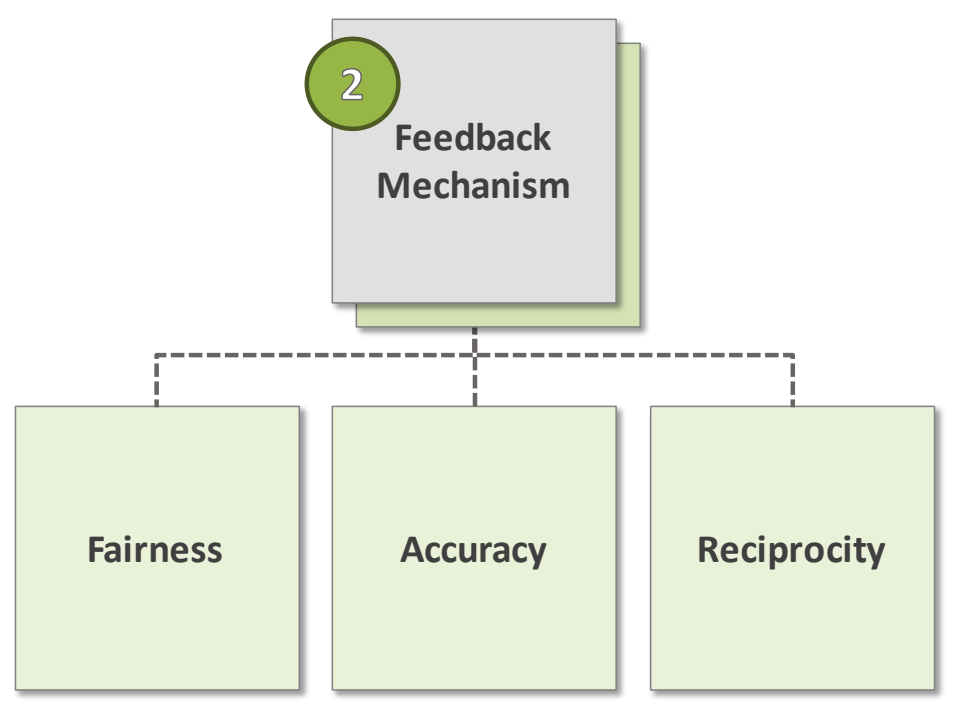

Figure 13: Code Structure for Feedback Mechanisms

To incentivize trustworthiness, sharing platforms employ reputation based feedback systems. This mechanism works in a form of indirect reciprocity, where information about participants can be shared among a network. For example, the key trust mechanism on Airbnb is the review feature, while Uber and other ride-sharing platforms rely on bilateral user ratings. Consequently, focus group respondents offered a variety of attitudes towards the use of ratings, reviews, and other feedback systems. Responses were coded accordingly and we distinguish between three main attitudes: ratings as unfair, ratings as inaccurate, and ratings as a reciprocal exchange.

Firstly, a key element of the discussion coded as fairness was how ratings were often perceived as being unfair, being based on a mixture of both legitimate and non-legitimate factors. However, attitudes varied over whether it was the system which needed to be changed, or whether users needed to be better informed about feedback criteria and what should count as a 'good' or 'bad' experience.

"Once, I gave one star less, not really bad, but I thought it was unfair because it was a very small car and I am just very tall. And I wanted to sit in the front on the passenger seat because I have the longest legs of all. And then the driver wrote to me that I had been very demanding. And if not having backache is already demanding, then I am demanding, yes." (M, 24, Germany) ${ }^{36}$

"A lot of people, they come there. They haven't really read the whole listing and they're like, "Oh, where's the TV?" I'm like, well, on the listing it says there isn't. Then, they will 
mark you down on it for things that you've already stated clearly is not there. That can affect also people's perceptions in a biased way." ( $M, 27$, Netherlands)

In line with their discussions over the fairness of certain ratings, respondents also questioned the overall accuracy of the rating systems, specifically whether they should view the ratings as representative given the tendency of reviewers who had average or mediocre experiences to not leave reviews at all. Thus, respondents discussed the skewed nature of reviews in general. One element that was also raised was the potential for reviews to be 'faked'. Overall, our respondents demonstrated a relatively sophisticated view of the ratings bias, suggesting that they were not approaching sharing economy services uncritically.

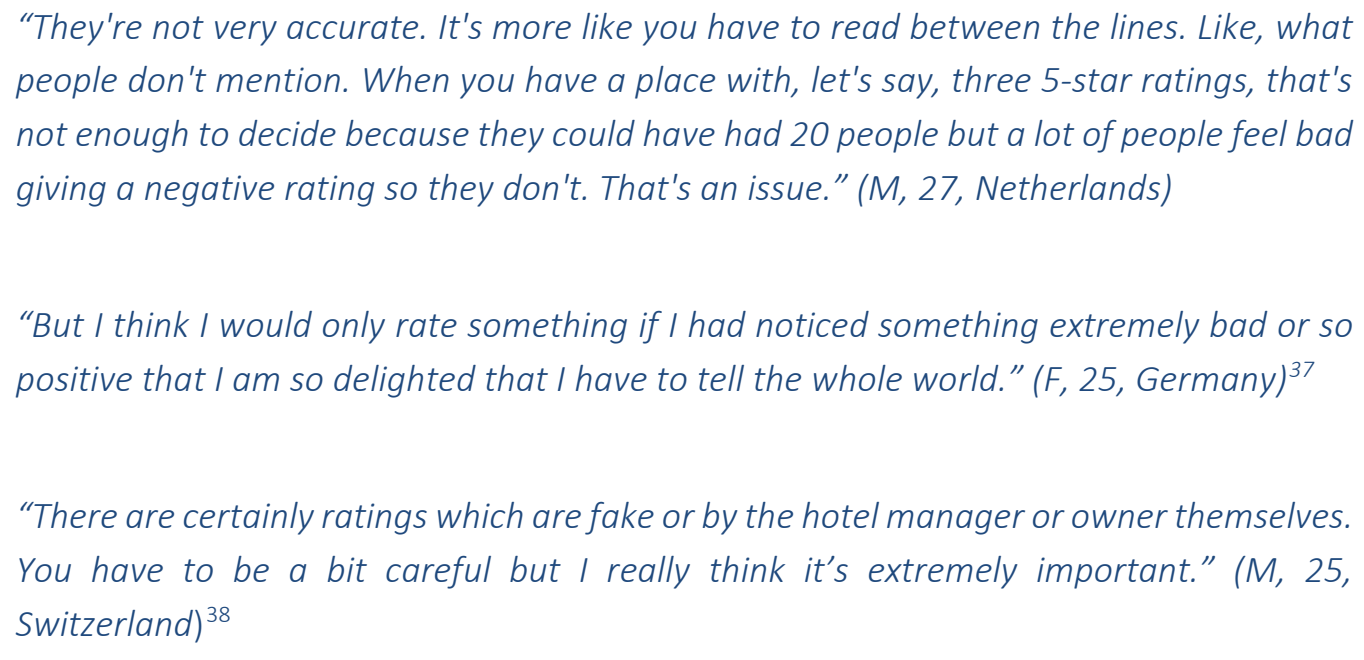

A critical tone when discussing the feedback systems was also prevalent when some respondents raised the reciprocal nature of ratings as a downside to the sharing economy. While the bilateral feedback systems act as an incentive for both parties to act acceptably in a transaction, not all respondents saw it so optimistically. Some respondents noted that the potential for feedback retribution, whereby a bad review would be met with a bad review in turn, limited their desire to be honest. In addition, some responses highlighted insecurities regarding the potential for bad feedback to hurt them in the future.

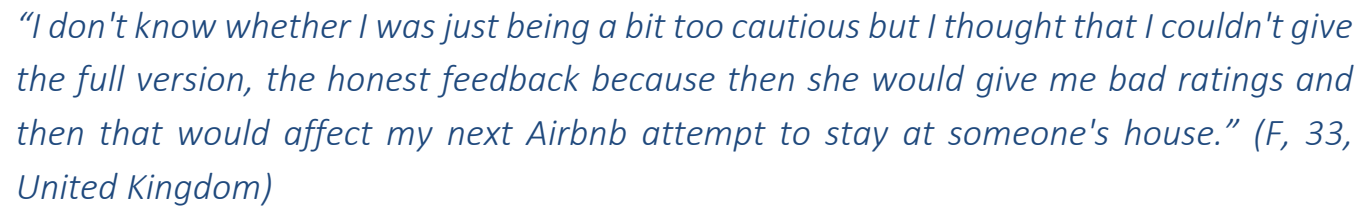


"I know on Airbnb, they actually rate you as well. So as a student, I get rated on mine and my one friend actually trashed a house and Airbnb has -- being stupid, got a really bad review and he can't book anymore Airbnbs because these people that he's booking from, the providers, like they actually look back at his reviews and I think that's important because they want their house to be respected." (M, 20, Norway)

Other respondents, however, from the perspective of providers, viewed the reciprocal nature of ratings as a positive element of the sharing economy, as it provided a level of security against bad behavior.

"Because if you're a guest and you have a bad review, they will actually investigate that. Like, if you do something really bad they will probably block you, so it is also kind of security for us." (F, 22, Netherlands)

"So, you also have unpunctual passengers and for you as a driver - then this person keeps getting bad ratings for not showing up. I think then it has advantages." ( $F, 25$, Germany) ${ }^{39}$

\subsection{Usability}

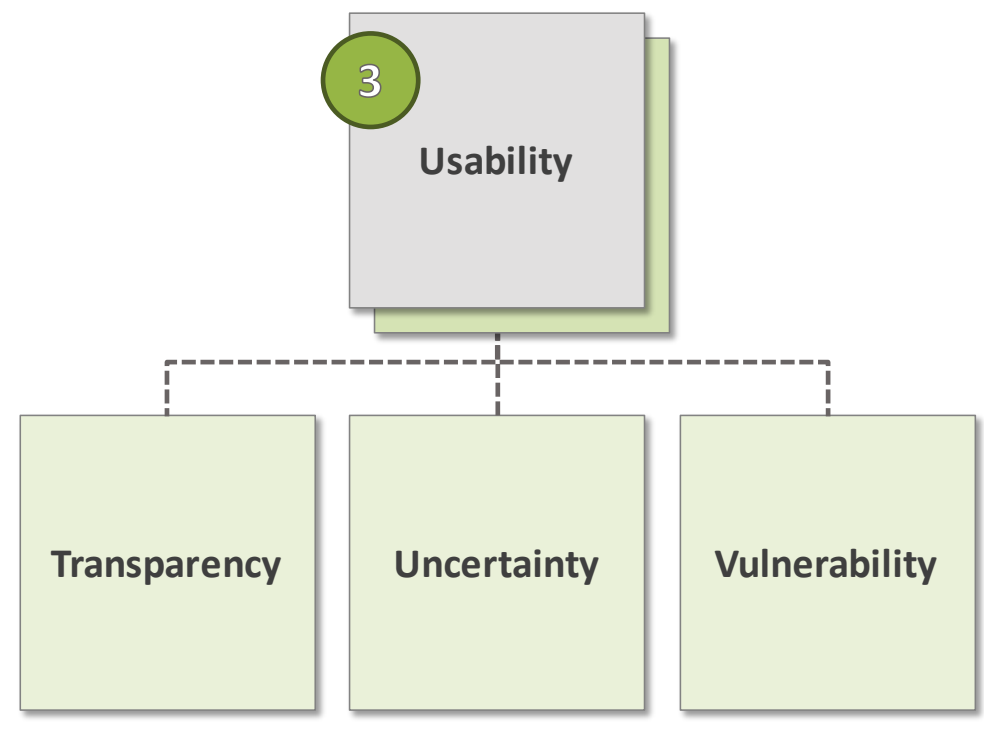

Figure 14: Code Structure for Usability

During the focus groups, respondents drew attention to the power dynamics between the user and the platform, largely within the scope of assessing the platform's usability. Firstly, some respondents 
praised the services for their transparency. In particular, respondents appreciated the element of technological intermediation, whereby their rides could be tracked by GPS to provide an element of safety. Interestingly, the transparency of the platforms was often presented as a relative factor, placed in contrast to traditional services such as taxis. Moreover, such discussions were often raised with regard to transportation services and as a gendered, predominantly female, concern. Given the potential for, and long-standing history of, gendered violence in taxis, that this was raised as a concern is not surprising.

"It's so much different because with Uber you can track it. And when it's wrong, you don't have to discuss with the driver. You can report it and you get your money back." (F, 25, Netherlands)

"But then with Uber it's so transparent, you can rate the driver, you could see what other people have rated them. You have their phone numbers like everything is logged by Uber, what you charged. If your charged wrong, if the driver cancels on you, if you cancel in the driver. I just think it's really nice way to make sure that -- it's like crime happens and everything it's really good if you can watch the GPS and everything." (F, 30, Norway)

"Actually, if you think about it, for me, I would have that question because I travel quite often by myself at night in London and I call an Uber just because I can send anyone in a text message my itinerary. They can actually follow where the car is and for me, that gives me a feeling of safety." ( $F$, 35, United Kingdom)

Certain respondents whose attitudes were less positive drew attention to the uncertainty of the sharing economy, with particular regard to home-sharing services. As opposed to ride-sharing, where variations in transport modality are limited due to sometimes strict platform restrictions, homesharing services cover a broad spectrum of services, leaving respondents uncertain about the quality or exact parameters of the service they will receive. Some respondents noted that this uncertainty also stretched to the hosts, since there may be a certain level of elevated self-presentation so as to receive more bookings.

"With Airbnb, you know in the end - based on the pictures, you can evaluate it but when you arrive there, you still don't know what to expect." (F, 24, Germany) 40

"But I was wondering about that. As I say, I'm a novice at this. I've only used Airbnb once but the person I stayed with, she put across a very rosy picture of herself, you know? She'd apparently been a retired teacher, loved travelling, loved seeing the world, you 
know, mix of people. I turned up there. She turned out to be not really having been a teacher. She'd been a ... what do you call them? A travel agent for most of her life but was a racist bigot and did not like anyone of any colour other than white." (F, 33, United Kingdom)

In a few instances, where respondents provided vivid descriptions of their own experiences, there was an underlying element of vulnerability. Users were reliant on the goodwill of their hosts to ensure access and ensure the safety of their stay. Whenever there was a misalignment of expectations, consumers had limited recourse and had to just accept what was the case, even if it left them in an unfortunate situation, such as without a place to stay. Due to the informal nature of bookings, there was no scope for resolution.

"For me, there is another point. Every location is different. When you stay for a night, it could be that you say to yourself that you want to use the day, for example in the US, at a certain place for leisure and you notice that the person says: "No you can't come yet, come between 11 and 12." But then she is not there but only the neighbor. He gives me this and that and then I ask: 'Where can I sleep?' 'Oh, I don't know, that's someone else.' Then I enter the place and there is the note but the key doesn't fit anymore or I have to return the key to a certain mailbox. And I think, but I have my computer and my stuff with me. There's no security at all." (M, 25, Switzerland) $)^{41}$

"I went to the reception. I said, 'Sorry, I rented through Airbnb.' He's like, 'No, you're going to get kicked out now.' I kind of felt bad for him but it's obviously a thing that, you know, you can obviously put anything, even apartments that are not supposed to be rented. I had to leave and I had no place to go. I had to look for a hotel and I had to go pick up a friend. I think that's ... from that perspective, there could be more checks, you know? You can literally put anything on." (M, 27, United Kingdom)

Further, there was uncertainty over liability in cases of damage. Due to the informal nature of the sharing economy, as well as the intermediary nature of platforms, respondents were unclear over who would be responsible if guests caused a mess or damage. Partly, users were reflective that they could have been more informed if they had made the effort to read the terms and conditions, but overall there was a sense of genuine uncertainty.

"But this process, that you really know that you are liable when something goes wrong. Like, if you, it's a stupid example, but if you leave a candle on and suddenly the whole flat is burning: What will happen? And who is responsible for it? I believe that we are very often not really aware about this anymore due to the short process between booking and 
completion of the contract. I could imagine that this is also a reason why many people say: 'Ok, I prefer to leave it well alone'." (F, 23, Germany) ${ }^{42}$

"I felt very sketchy if I didn't know what the app or what the service actually would cover if I crashed the car, or if something happened and so on." (F, 30, Norway)

"The room, if you rent out rooms and someone comes and destroys the room, then the contract has nothing to do with the platform. It is between the person renting out the room and the person renting the room. That means, if that person flies back to Asia on the next day and half the room is missing, then the contract emerged between you and that person." (F, 27, Switzerland $)^{43}$

Uncertainty was also a topic which emerged through a non-user lens, since some respondents expressed their vulnerability to risk when neighbors provide their homes on sharing platforms. In such a situation, the benefits of sharing accrue to the provider, but the whole community or neighborhood has to face the potentially negative consequences of sharing, such as unruly or loud guests.

"So yeah, I think the neighbor would expose me to a risk, yeah, because we don't know what kind of people are coming. So obviously, I would be irritated if there will be party people that don't respect sleeping hours, let's say, but I don't know." (F, 28, Norway)

"It depends on customer control like if your neighbor like to meet new people, it's great experience for him or her. But if it's party people who just arrive every single week, new ones, it's not the best experience you could have as a neighbor for Airbnb flat." ( $F, 22$, Norway)

\subsection{Regulation}




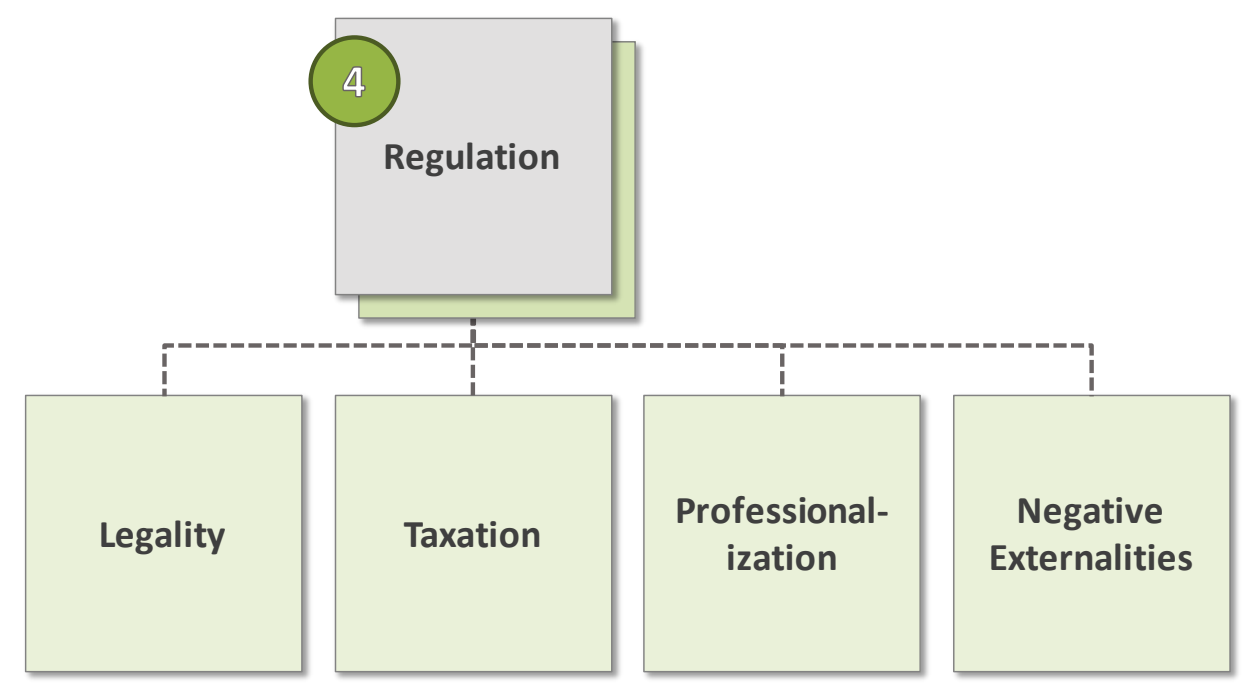

Figure 15: Code Structure for Regulation

A majority of respondents demonstrated regulatory concerns. Indeed, one of the most prominent themes was a vagueness over the current regulatory status quo of sharing economy companies. Based on a number of respondents who experienced negative interactions with law-enforcement during sharing transactions, legality emerged as a topic which attracted tangible concerns. Moreover, some respondents perceived this legal uncertainty as requiring additional effort on their behalf, in the form of pretending not to be using sharing economy services. In such an instance, respondents' experiences are negatively coloured with the idea that they are doing something wrong.

"And I was sure that there's not prohibited to know it, I just found out it for like a months ago when my friends told me a story how they went to the airport and couldn't find a taxi, and then took Uber and one was stopped by the police." (F, 22, Norway)

"I forgot to mention it here - but with Uber, which I like to use regularly, for example in Thailand, I had the negative experience that they are often searched after by the police respectively also protection money. And it's mostly the case [laughter in the background] that Uber in many countries, from a purely legal point of view, as a driver you are not sure in which countries it is actually allowed. You know from the press, in Germany it doesn't work well, in the US it works well. In Thailand, they are sometimes controlled very closely by the police. And during an Uber ride, a policeman came in and we had to pretend as if we had some other agreed rides because the driver had briefed us. You feel a bit unwell in such cases, to have to say: 'Ok, I'm not a Uber user', just to protect this guy somewhat." (M, 24, Germany) ${ }^{44}$ 
In addition to legality as a topic, focus group respondents engaged in lively debates about whether sharing economy services should be taxed. One perspective, held by a large number of respondents, was that taxation should be enforced but only for those situations where sharing is happening in a quasi-professional capacity. Where the line was to be drawn, however, between casual and noncasual use was left unresolved.

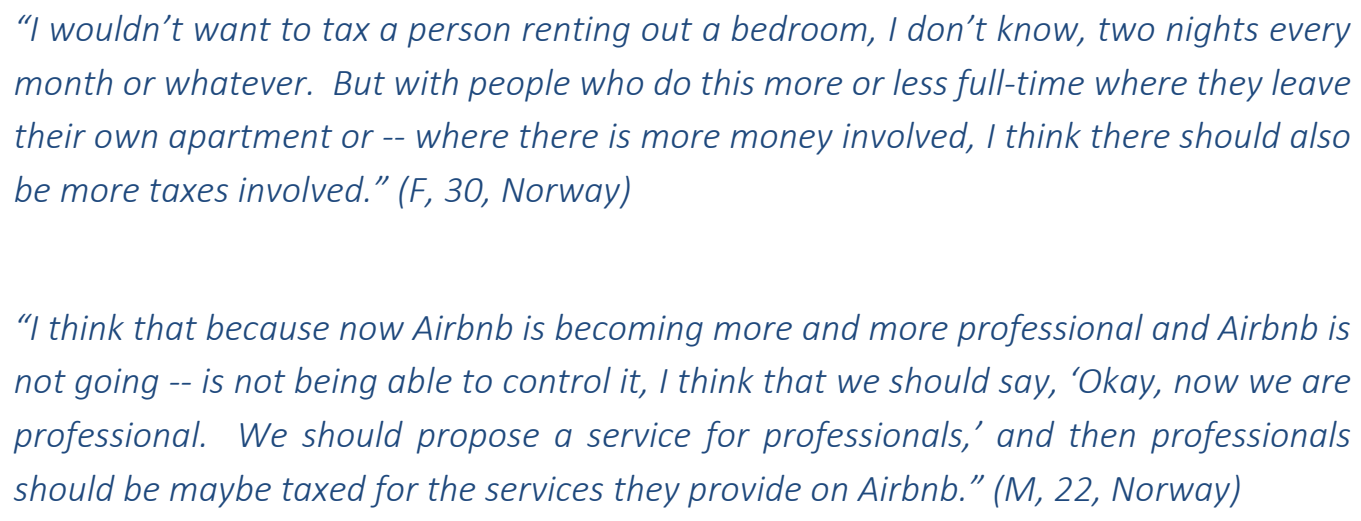

However, an interesting attitude that developed was that respondents, while pro-taxation in the general sense, were unwilling to agree to more taxation if it negatively impacted them by increasing prices. As such, users presented a somewhat hypocritical, yet self-aware, attitude of self-interest. More striking was that this attitude was very prominent even in highly-taxed countries such as Norway.

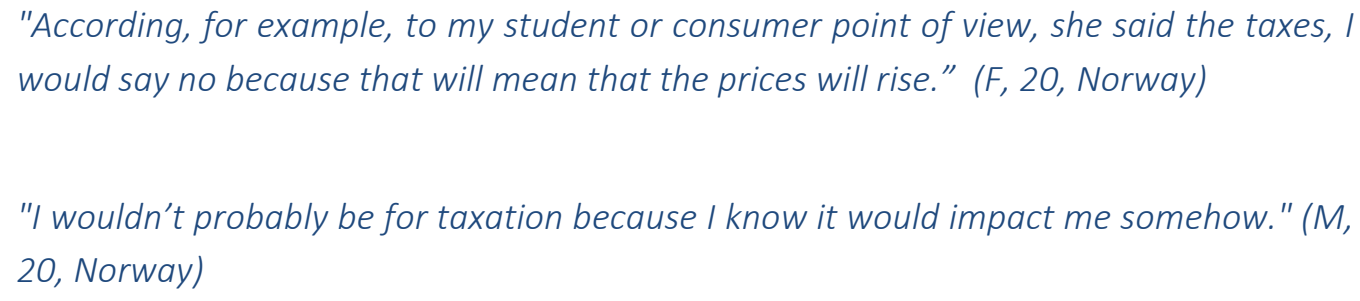

The professionalization of the sharing economy emerged as a topic of great interest among focus group respondents, many of whom viewed professionalization as an unavoidable eventuality in light of the commercial possibilities of sharing. Some participants hinted that there could be benefits from professionalization, such as reduced uncertainty. However, despite the benefits, some respondents elaborated that such professionalization was no longer conceptually part of the 'sharing economy'.

"I think that over the years, the whole thing became more professional. I think in the beginning, also with Airbnb, I had much more communication problems: How do I get into the flat? Where is the key and so on? Also with Mitfahrgelegenheit in the past: 
Where do you meet? Nowadays, it's pre-programmed in a way that you can ask for the meeting point in some way and you don't have to write a text yourself but just click something, and the communication altogether was just professionalized." ( $F, 25$, Germany) ${ }^{45}$

"I think to me sharing economy is something about not sort of when you're not doing it professionally. When it's not your job and when you don't have this elemental -- I don't know, education or something related to it, you're just doing it on a site in the legal sense." (F, 25, Norway)

Connected to the idea of the greater professionalization, some respondents raised concerns over the negative externalities which emerge from the sharing economy. One of the most critical issues, raised particularly by respondents in capital cities, was the housing congestion as a result of providers buying property to rent on the home-sharing market.

"As from my eyes, I think it's... The idea's good, but when stuff like, there is no more rooms available in Amsterdam, the price are going up, people are buying apartments and renting it out 24/7." (F, 20, Netherlands)

"I think that would lead to many apartments being bought up for this specific thing and then that would lead to those people wanting to live in the cities being brushed up which already happens." (M, 29, Norway) 


\subsection{Labor Issues}

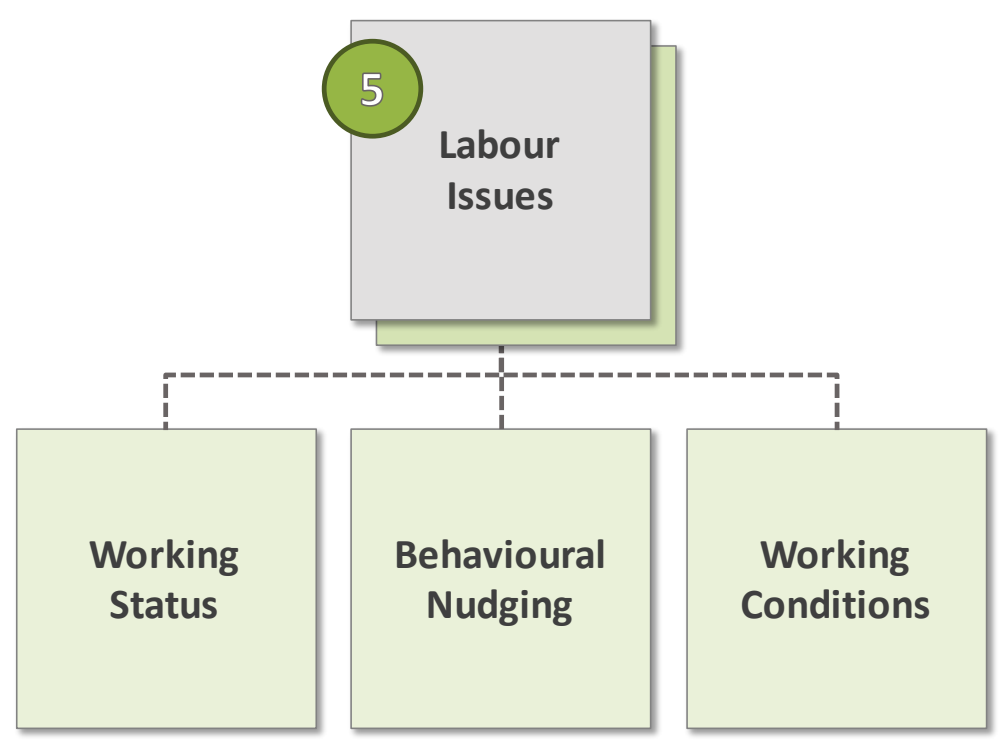

Figure 16: Code Structure for Labor Issues

As a key theme which emerged from the focus groups, respondents displayed an interest in the role of their providers as workers. Particularly, there was a level of discourse over how providers interacted with the platform and how that impacted their attitude towards sharing economy services and providers. Firstly, as a fundamental discussion that was held, the majority of respondents showed an awareness of the debate surrounding the working status of providers. The predominant viewpoint was that providers were self-employed or freelancing, rather than employees of the platform. Interestingly, respondents who were providers themselves shared this evaluation, self-identifying as non-employees.

"I think when you're looking at these platforms, if you really think about that these people are self-employed. Pretty much they're employing themselves to these platforms." (M, 20, Norway)

"So it doesn't change my view at least of how l look at them. They will not be an employee of Airbnb even though they do it full-time at least I think." (F, 30, Norway)

"(It's necessary to) provide rules, to name things; say - if I'm a freelancer and I'm taking part in the sharing economy, that's fine - I'm just doing additional work and maybe something I like, on which I earn a little extra, but nothing excessive. If I'm an 
employee...I'm an employee of someone, as such I work a certain number of hours and request that such hours are paid a fair amount." $(F, 25 \text {, Italy })^{46}$

However, complicating discussions of working status, the majority of respondents were seemingly aware that providers could be removed from the platform in the face of negative ratings, which acted as a form of control. To some respondents, the ability of platforms to 'fire' providers acted as evidence for employee status.

"The fact that Uber can actually fire its drivers. Let's say not because of health and safety but because they're just not, maybe they got a lot of low ratings because they're not very friendly. That starts to make a part of the distinction of, are they a part of the company or not? Are they employees? That makes it less of a blur, in that they are employees." ( $M, 27$, Netherlands)

Similarly, some respondents showed concern over the role of the platform in attempting to manage or shape the sharing transaction through behavioral nudging. Partly, this is enacted through providing direct information on how to perform as 'better' providers, even when the materials are perceived as an over-extension of the platform's role. As self-identified non-employees, such attempts at management are viewed unfavorably and as an intrusion on provider freedom.

"For some reason, I didn't accept or refuse. Now, it starts like, warning, guests need to have good experience so when they are searching something and they're requesting something and you reject, they don't feel good. I'm like, seriously people? It's my house. If I don't want to book these people, then I don't want to book these people. They should understand." (F, N/A, Netherlands)

"But we have to understand as well, they are in a very difficult position. Like a middle person between the customers and also the service providers. Also, it's very difficult for them to make both sides happy. If the customers keep demanding more, what can they do? They will send you materials to teach you how to become a better host. You know what I'm trying to say." (F, 32, Netherlands)

As a final issue, it was clear that there is an ongoing discourse surrounding the working conditions of certain providers, particularly in the ride-hailing sector. Some respondents noted that they had been made aware of the problems by providers themselves, providing an interesting framing for how these issues are perceived, with their opinions being externally shaped rather than internally sourced. One prominent issue was the level of payment received by providers, whether it is of sufficient size and 
whether the platform takes too large of a 'cut'. Overall, there was an awareness among consumers that providers make less money than they had previously thought, with a disconnect between their expectations and reality.

"I heard they don't get paid well. At all....I read that the customers were charged a lot more than what they get. I read there is even some mechanism where they can look up how much the customer was charged and how much they got. Basically, they sometimes communicate to the drivers the different charge they made." ( $M, 35$, Netherlands)

"I would like to know maybe more about the commission, the professional sort of take, because I think this is much higher than what we thought. For example Airbnb, when we paid for example 100 Euros, how much is the commission and how much does the host earn really? And same for Uber because the driver used to complain because they're not paid enough, so that would be the information with information about their job. If haven't pay rent a year, Uber drivers are always complaining. They're going to take Uber and you talk with them that this is the main topic. They always say, 'Oh my god, Uber is such a -- they are so dishonest. They take all the money that we don't have. We don't get enough money, that's why we have to drive the whole week.'" ( $M, 22$, Norway)

"However, I read pretty much everywhere that they complained about not earning enough to make it to the end of the month" $(F, 23, \text { Italy })^{47}$ 


\section{Key Conclusions}

This research is based on qualitative data collected from a sample of Millennial consumers of the Sharing Economy, focusing on their experience of participation, privacy, and power in the sharing economy. Based on the data from a total of 18 focus groups, we identified several themes that appear to shape the interactions and experiences of young adults using the sharing economy.

\section{Motives and Outcomes}

Despite the strong emphasis sharing platforms put on the value of peer relationships, the social aspect of the sharing economy did not appear to be a very important motivation for respondents' participation. Participants in the focus groups rather referred to the economic advantages sharing economy services offer over traditional alternatives. When sharing economy options are not perceived to be sufficiently less expensive than traditional services, some respondents reported being happier to employ the latter.

Interestingly, the social value of the sharing economy appears more strongly as an outcome from participation than a as a motive. However, also when it comes to outcomes, the economic benefits brought about by participation take priority, highlighting a rather utilitarian use of sharing platforms.

A somewhat surprising finding was the emergence of users-by-proxy, a category of individuals who operate in the sharing economy indirectly because of lack of skills, lack of resources (such as credit cards or smart phones) or very high privacy concerns. Respondents reported acting as an intermediary between users-by-proxy (often older relatives) and the sharing economy.

Overall, our results could be at least partially motivated by the nature of the sample, as especially the younger Millennial consumers, possibly not yet in permanent employment, might be faced with a smaller budget and therefore be more sensitive to the cost savings offered by sharing economy services. A more multi-generational approach could offer interesting differences in motives and outcomes, hence further research should be conducted to find out if the social benefits of sharing are more relevant for older users.

\section{Peer Relations}

Even though peer-to-peer interaction might not represent one of the main drivers of participation on sharing platforms, it still represents an important part of the consumer experience. The analysis of our focus group responses seemed to suggest several ways in which relationships with other users shape Millennial consumers' experience of the sharing economy.

Sometimes, users' relationships towards peers are perceived as an obstacle to access the sharing economy. The analysis of respondents' participation uncovered an existing trade-off between users' personal network outside of sharing platforms and the services being offered on the platforms. In 
fact, some respondents signaled how they would use home- or transportation-sharing services only when they couldn't get the same hospitality from friends and family.

When approaching themes of privacy and information sharing, respondents reported higher concerns around peer-related risks of data misuse compared to platform-related concerns. Additionally, several respondents highlighted how the risks they see in offline peer interaction prevent them from considering to share their possessions with others online as providers, which is considered an inherently more vulnerable role. Because of perceived risks relating to peer interaction, respondents report engaging in risk reduction strategies, such as monitoring a provider's use of words or pictures, so as to minimize the potentials for fraud.

Peer relations appear to also be the source of what respondents perceive as power imbalances. As consumers in the sharing economy, focus groups participants reported feeling the emotional burden connected to forced sociability. Some respondents felt that fulfilling providers' expectations towards an amicable interaction was an additional cost to participation.

Overall, results to our analysis suggest that users have a rather complex attitude to peer relations within the sharing economy, and that, overall, they might consider their value as more nuanced than the media narratives around sharing platforms might suggest. As such, we think that further research could help better explain how consumers and providers interact within the sharing economy.

\section{Feedback Systems and Reviews}

An important element of users' experience of the sharing economy stands in the feedback systems of platforms. Respondents highlight how the reciprocity of review systems constitutes a motivation for repeated participation; consumers report a higher motivation to rate someone positively if they have the expectation that this might correspond to a similarly positive review.

Millennial consumers within our sample report using feedback systems to establish trust towards their peers; not just the amount, but also the content and quality of reviews point to reliable providers of services. According to respondents, a working feedback system is also signal of trustworthiness for platforms, as it facilitates a fair and informed exchange between consumers and providers.

While respondents actively use ratings and reviews to choose providers, they also signal instances of inaccuracy and unfairness, such as a certain positivity bias in which both sides minimize negative experiences to avoid a negative review. Several participants to focus groups highlighted how a certain degree of familiarity might be necessary in order to truly decipher the meaning of reviews.

\section{Regulation and Labor}

Perhaps influenced by media debates, respondents reported an interest in the evolution of local regulations around sharing platforms. Millennial consumers in our focus groups expressed discomfort 
in using services whose legality is sometimes ambiguous; many among the respondents expressed the wish for governments to more clearly guarantee platforms a legal status.

A more nuanced approach is taken when it comes to taxation. While the majority of respondents highlights how forcing platforms to pay taxes might be essential for their full legality, some express concerns over what consequences such changes might have on the services. In particular, some respondents worry that a stricter taxation might drive up the prices of sharing services, making them inaccessible for consumers.

Another focus is labor conditions. While respondents characterize services like home-sharing as entrepreneurial and fair, they perceive ride-sharing, for example, as having the potential for labor unfairness and exploitation. Overall, more research could help better understand how participants to the sharing economy feel about the platforms' legal status and emerging labor issues. 


\section{References}

Anderson, J., \& Rainie, L. (2010). Millennials will make online sharing in networks a lifelong habit. Pew Research. Retrieved from Pewinternet.org website: http://pewresearch. org/millennials.

Andreotti, A., Anselmi, G., Eichhorn, T., Hoffmann, C. P., \& Micheli, M. (2017). Participation in the Sharing Economy. SSRN Electronic Journal. Retrieved from https://ssrn.com/abstract=2961745

Andreotti, A., Anselmi, G., Eichhorn, T., Hoffmann, C. P., Jürss, S., \& Micheli, M. (2017). Participation in the Sharing Economy: European Perspectives. SSRN Electronic Journal. Retrieved from https://ssrn.com/abstract $=3046550$

Belk, R. (2014). You are what you can access: Sharing and collaborative consumption online. Journal of Business Research, 67(8), 1595-1600.

Godelnik, R. (2017). Millennials and the sharing economy: Lessons from a 'buy nothing new, share everything month' project. Environmental Innovation and Societal Transitions, 23, 40-52.

Newlands, G., Lutz, C., \& Fieseler, C. (2017a). Power in the Sharing Economy. SSRN Electronic Journal. Retrieved from https://ssrn.com/abstract $=2960938$

Newlands, G., Lutz, C., \& Fieseler, C. (2017b). Power in the sharing economy: European Perspectives. SSRN Electronic Journal. Retrieved from https://ssrn.com/abstract=3046473

Xu, Y., Johnson, C., Bartholomae, S., O'Neill, B., \& Gutter, M. S. (2015). Homeownership among millennials: The deferred American dream?. Family and Consumer Sciences Research Journal, 44(2), 201-212.

Klein, N. J., \& Smart, M. J. (2017). Millennials and car ownership: Less money, fewer cars. Transport Policy, 53, 20-29.

Maycotte, H.O. (2015). Millennials are driving the Sharing Economy - And So Is Big Data. Forbes. Retrieved from Forbes.com website:

https://www.forbes.com/sites/homaycotte/2015/05/05/millennials-are-driving-the-sharingeconomy-and-so-is-big-data/\#69720d78cb50

Ranzini, G., Etter, M., Lutz, C., \& Vermeulen, I. E. (2017). Privacy in the sharing economy. SSRN Electronic Journal. Retrieved from https://papers.ssrn.com/sol3/papers.cfm?abstract id=2960942

Ranzini, G., Etter, M., \& Vermeulen, I. E. (2017). Privacy in the sharing economy: European Perspectives. SSRN Electronic Journal. Retrieved from https://papers.ssrn.com/sol3/papers.cfm?abstract id=3048152 


\section{Appendix 1 - Methodology}

The method used for this research was to carry out semi-structured focus group interviews, with a sample of both consumers and providers of sharing economy services. Interview questions were developed based on the themes identified in the first phase of the project and pre-tested internally.

A total of 18 focus groups were conducted in the six participating countries: Germany (Leipzig), Italy (Milan), The Netherlands (Amsterdam), Norway (Oslo), Switzerland (St Gallen), and The United Kingdom (London). Focus groups were conducted on location at the participating universities.

Participants were recruited on the basis of the following guidelines:

- Participants had to be either consumers or providers of sharing economy services.

- Participants had to be aged between 20 and 35.

Participation by students of the consortium universities was permitted, provided that students had not previously taken part in courses explicitly referencing any of the themes within the study. Some participants older than 35 took part in the focus groups. Their data was collected but not analyzed for the sake of this research. One respondent guaranteed she was younger than 35 years old, but refused to provide any other detail; her responses were considered within our analysis.

Recruitment guidelines were straightforward and the recruitment process did not encounter major difficulties. The measures taken from the consortium to ensure quality, as well as respect of participants' data are listed below.

\section{Recruitment}

Eligibility of participants was checked at recruitment and confirmed before their participation. Additionally, before the start of the interviews, participants were asked to fill in a small demographic questionnaire and sign a waiver to confirm their willingness to participate in the study.

\section{Organization}

Each focus group covered one of the three key themes within the project: Participation, Privacy, and Power. Each consortium team attempted, to the best of their ability, to cover all themes in their location with a minimum of three focus groups.

In introducing the focus groups, respondents were also asked to describe their use of sharing economy platforms, and to define, or debate, on possible definitions for the sharing economy. As natural in the focus group form, dialogue among participants was encouraged and facilitated. All focus group interviews were recorded and saved.

\section{Analysis}

Data analyses were conducted at a local level, by each team. Data was approached thematically, employing a combination of inductive and deductive methods. 


\section{Translation}

The focus groups which took place in The Netherlands, Norway, and the United Kingdom were conducted in English. The rest of focus groups were conducted in local languages and translated by the consortium. All un-translated quotes are reported at the end of this document.

\section{Appendix 2-Respondents Profiles}

\begin{tabular}{|c|c|c|c|c|c|c|}
\hline $\begin{array}{l}\text { Participant } \\
\text { Number }\end{array}$ & $\begin{array}{l}\text { Focus } \\
\text { Group }\end{array}$ & Gender & Age & Nationality & Profession & $\begin{array}{l}\text { Role in the } \\
\text { Sharing } \\
\text { Economy }\end{array}$ \\
\hline \multicolumn{7}{|c|}{ The Netherlands (Amsterdam) } \\
\hline 1 & 1 & $\mathrm{~F}$ & 28 & Chinese & Student & Consumer \\
\hline 2 & 1 & $\mathrm{~F}$ & 29 & Polish & Student & Consumer \\
\hline 3 & 1 & $\mathrm{~F}$ & 25 & Dutch & Student & Consumer \\
\hline 4 & 2 & $\mathrm{~F}$ & 20 & Dutch & Student & Consumer \\
\hline 5 & 2 & $M$ & 22 & Dutch & Student & Consumer \\
\hline 6 & 2 & $M$ & 20 & Dutch & Student & Consumer \\
\hline 7 & 2 & $\mathrm{M}$ & 24 & Dutch & Student & Consumer \\
\hline 8 & 2 & $\mathrm{~F}$ & 20 & Dutch & Student & Consumer \\
\hline 9 & 2 & $\mathrm{~F}$ & 30 & Dutch & Student & Consumer \\
\hline 10 & 2 & $\mathrm{~F}$ & 21 & Dutch & Student & Consumer \\
\hline 11 & 3 & $\mathrm{~F}$ & 19 & Dutch & Student & Consumer \\
\hline 12 & 3 & $M$ & 21 & Dutch & Student & Consumer \\
\hline 13 & 3 & $\mathrm{~F}$ & 19 & Dutch & Student & Consumer \\
\hline 14 & 3 & $F$ & 34 & British & Employee & $\begin{array}{l}\text { Consumer \& } \\
\text { Provider }\end{array}$ \\
\hline 15 & 3 & $F$ & 29 & Dutch & Student & Consumer \\
\hline 16 & 3 & $\mathrm{~F}$ & 19 & Dutch & Student & Consumer \\
\hline 17 & 3 & $\mathrm{~F}$ & 22 & Dutch & Student & Consumer \\
\hline 18 & 3 & $\mathrm{~F}$ & 25 & Spanish & Student & Consumer \\
\hline 19 & 3 & $\mathrm{~F}$ & 19 & Dutch & Student & Consumer \\
\hline 20 & 4 & $\mathrm{~F}$ & 26 & Russian & Student & Consumer \\
\hline 21 & 4 & $\mathrm{~F}$ & 22 & Dutch & Student & Consumer \\
\hline 22 & 4 & $M$ & 25 & Dutch & Lecturer & Consumer \\
\hline 23 & 4 & $M$ & 20 & Dutch & Student & Consumer \\
\hline 24 & 5 & $M$ & 29 & Serbian & Engineer & Consumer \\
\hline 25 & 5 & $F$ & 27 & Serbian & Volunteer & Consumer \\
\hline 26 & 5 & $M$ & 39 & British & Freelance & $\begin{array}{l}\text { Consumer \& } \\
\text { Provider }\end{array}$ \\
\hline
\end{tabular}




\begin{tabular}{|l|l|l|l|l|l|l|}
\hline 27 & 5 & M & 27 & Singapore & Engineer & Consumer \\
\hline 28 & 5 & F & 32 & Dutch & Consultant & Consumer \\
\hline 29 & 5 & F & N/A & N/A & N/A & $\begin{array}{l}\text { Consumer \& } \\
\text { Provider }\end{array}$ \\
\hline 30 & 5 & M & 35 & Indian & Consultant & $\begin{array}{l}\text { Consumer \& } \\
\text { Provider }\end{array}$ \\
\hline
\end{tabular}

\begin{tabular}{|l|l|l|l|l|l|l|}
\hline $\begin{array}{l}\text { Participant } \\
\text { Number }\end{array}$ & $\begin{array}{l}\text { Focus } \\
\text { Group }\end{array}$ & Gender & Age & Nationality & Profession & $\begin{array}{l}\text { Role in the } \\
\text { Sharing } \\
\text { Economy }\end{array}$ \\
\hline \multicolumn{7}{|c|}{ Norway (Oslo) } \\
\hline 32 & 6 & F & 26 & Romanian & Student & Consumer \\
\hline 33 & 6 & F & 25 & Ukrainian & Student & Consumer \\
\hline 34 & 6 & M & 30 & Norwegian & Student & Consumer \\
\hline 35 & 6 & M & 31 & Norwegian & Student & Consumer \\
\hline 36 & 7 & F & 30 & Norwegian & Student & Consumer \\
\hline 37 & 7 & M & 20 & French & Student & Consumer \\
\hline 38 & 7 & F & 20 & American & Student & Consumer \\
\hline 39 & 7 & M & 22 & French & Student & Consumer \\
\hline 40 & 7 & M & 20 & Canadian & Student & Consumer \\
\hline 41 & 8 & F & 28 & Ukrainian & Student & Consumer \\
\hline 42 & 8 & F & 28 & Romanian & Student & Consumer \\
\hline 43 & 8 & F & 22 & Ukrainian & Student & Consumer \\
\hline 44 & 8 & M & 29 & Norwegian & Employee & Consumer \\
\hline 45 & 8 & F & 30 & Norwegian & Project & Consumer \\
& & & & & & \\
\hline
\end{tabular}

\begin{tabular}{|l|l|l|l|l|l|l|}
\hline $\begin{array}{l}\text { Participant } \\
\text { Number }\end{array}$ & $\begin{array}{l}\text { Focus } \\
\text { Group }\end{array}$ & Gender & Age & Nationality & Profession & $\begin{array}{l}\text { Role in the } \\
\text { Sharing } \\
\text { Economy }\end{array}$ \\
\hline \multicolumn{7}{|c|}{ Germany (Leipzig) } \\
\hline 46 & 9 & M & 24 & German & Student & Consumer \\
\hline 47 & 9 & M & 26 & German & Student & Consumer \\
\hline 48 & 9 & F & 23 & German & Student & Consumer \\
\hline 49 & 9 & M & 25 & German & Student & Consumer \\
\hline 50 & 9 & M & 26 & German & Student & Consumer \\
\hline 51 & 10 & F & 23 & German & Student & Consumer \\
\hline 52 & 10 & F & 24 & German & Student & Consumer \\
\hline 53 & 10 & F & 23 & German & Student & Consumer \\
\hline 54 & 11 & F & 26 & German & Student & Consumer \\
\hline
\end{tabular}




\begin{tabular}{|l|l|l|l|l|l|l|}
\hline 55 & 11 & F & 24 & German & Student & Consumer \\
\hline 56 & 11 & M & 24 & German & Student & Consumer \\
\hline 57 & 11 & F & 22 & German & Student & Consumer \\
\hline 58 & 11 & F & 25 & German & Student & Consumer \\
\hline 59 & 11 & F & 24 & German & Student & Consumer \\
\hline 60 & 11 & F & 24 & German & Student & Consumer \\
\hline
\end{tabular}

\begin{tabular}{|c|c|c|c|c|c|c|}
\hline $\begin{array}{l}\text { Participant } \\
\text { Number }\end{array}$ & $\begin{array}{l}\text { focus } \\
\text { group }\end{array}$ & Gender & Age & Nationality & Profession & $\begin{array}{l}\text { Role in the } \\
\text { Sharing } \\
\text { Economy }\end{array}$ \\
\hline \multicolumn{7}{|c|}{ Italy (Milan) } \\
\hline 61 & 12 & $F$ & 24 & Italian & Student & Consumer \\
\hline 62 & 12 & $\mathrm{~F}$ & 23 & Italian & Student & Consumer \\
\hline 63 & 12 & $\mathrm{M}$ & 24 & Italian & Student & Consumer \\
\hline 64 & 12 & $M$ & 25 & Italian & Student & Consumer \\
\hline 65 & 12 & $F$ & 24 & Italian & Student & Consumer \\
\hline 66 & 12 & $\mathrm{~F}$ & 25 & Italian & Student & Consumer \\
\hline 67 & 12 & $M$ & 24 & Italian & Student & Consumer \\
\hline 68 & 12 & $M$ & 25 & Albanian & Student & Consumer \\
\hline 69 & 13 & $\mathrm{~F}$ & 26 & Italian & Student & Consumer \\
\hline 70 & 13 & $F$ & 24 & Italian & Student & Consumer \\
\hline 71 & 13 & $\mathrm{M}$ & 29 & Italian & Student & $\begin{array}{l}\text { Consumer \& } \\
\text { Provider }\end{array}$ \\
\hline 72 & 13 & $F$ & 20 & Italian & Student & Consumer \\
\hline 73 & 13 & $F$ & 51 & Italian & Student & $\begin{array}{l}\text { Consumer \& } \\
\text { Provider }\end{array}$ \\
\hline 74 & 13 & $M$ & 25 & Italian & Student & $\begin{array}{l}\text { Consumer \& } \\
\text { Provider }\end{array}$ \\
\hline 75 & 14 & $F$ & 25 & Italian & Student & Consumer \\
\hline 76 & 14 & $\mathrm{~F}$ & 24 & Italian & Student & Consumer \\
\hline 77 & 14 & $F$ & 23 & Italian & Student & Consumer \\
\hline 78 & 14 & $M$ & 26 & Italian & Student & Consumer \\
\hline 79 & 14 & $\mathrm{~F}$ & 33 & Italian & Student & Consumer \\
\hline
\end{tabular}

\begin{tabular}{|l|l|l|l|l|l|l|}
\hline $\begin{array}{l}\text { Participant } \\
\text { Number }\end{array}$ & $\begin{array}{l}\text { focus } \\
\text { group }\end{array}$ & Gender & Age & Nationality & Profession & $\begin{array}{l}\text { Role in the } \\
\text { Sharing } \\
\text { Economy }\end{array}$ \\
\hline \multicolumn{7}{|c|}{ Switzerland (St. Gallen) } \\
\hline 75 & 15 & F & 27 & Swiss & Student & Consumer \\
\hline 76 & 15 & M & 41 & Swiss & Student & Consumer \\
\hline
\end{tabular}




\begin{tabular}{|l|l|l|l|l|l|l|}
\hline 77 & 15 & M & 31 & German & Student & Consumer \\
\hline 78 & 15 & M & 24 & German & Student & Consumer \\
\hline 79 & 15 & M & 29 & Swiss & Student & Consumer \\
\hline 80 & 16 & F & 37 & Swiss & Student & Consumer \\
\hline 81 & 16 & F & 52 & German & Student & Consumer \\
\hline 82 & 16 & F & 32 & German & Student & Consumer \\
\hline 83 & 16 & F & 36 & German & Student & Consumer \\
\hline 84 & 16 & M & 28 & German & Student & Consumer \\
\hline 85 & 17 & M & 25 & Italian & Student & Consumer \\
\hline 86 & 17 & M & 25 & Swiss & Student & Consumer \\
\hline 87 & 17 & F & 45 & German & Student & Consumer \\
\hline 88 & 17 & F & 23 & German & Student & Consumer \\
\hline 89 & 17 & M & 44 & Austrian & $\begin{array}{l}\text { Executive } \\
\text { Director }\end{array}$ & Consumer \\
\hline
\end{tabular}

\begin{tabular}{|l|l|l|l|l|l|l|}
\hline $\begin{array}{l}\text { Participant } \\
\text { Number }\end{array}$ & $\begin{array}{l}\text { Focus } \\
\text { Group }\end{array}$ & Gender & Age & Nationality & Profession & $\begin{array}{l}\text { Role in the } \\
\text { Sharing } \\
\text { Economy }\end{array}$ \\
\hline \multicolumn{7}{|c|}{ The United Kingdom (London) } \\
\hline 90 & 18 & M & 27 & Croatian & Student & Consumer \\
\hline 91 & 18 & F & 33 & Spanish & Student & Consumer \\
\hline 92 & 18 & F & 35 & Hungarian & Student & Consumer \\
\hline 93 & 18 & M & 30 & Italian & Student & Consumer \\
\hline 94 & 18 & F & 33 & German & Student & Consumer \\
\hline
\end{tabular}

\section{Appendix 3 - Focus Groups Guidelines}

\section{Introduction}

Thank you for joining this group discussion on the sharing economy. This discussion will focus on aspects of [privacy/power/participation] in particular. Before we look at these aspects though, let's start with a brief introductory round. Can you each just say a couple of words about yourself and your background? Thank you, now let's tackle our topic. Could each of you briefly list sharing services that you know or have used in the past.

\section{Objective: Collecting Platforms}

Focusing on platforms, that you have used in the past...

How did you find these platforms? How did you learn about them? 
What did you look at when deciding to start using them?

\section{Objective: Establishing a common definition}

Alright, now we've heard quite a few different experiences with the sharing economy. Maybe it would be helpful to clarify a bit what we mean by "sharing economy". What do you think - what is the "sharing economy"?

\section{Participation Questionnaire}

Now we have defined what we mean by Sharing Economy and we have listed a number of services or platforms. Could you please describe your use of these platforms. What did you do on these platforms, how did you use them?

\section{Objective: Collect both providers' and consumers' perspectives}

What activities have you performed on the platform? How did you participate on the platform? How did you interact with the platform provider? How did you experience these interactions?

\section{Theme 1: Motives}

How did you become aware of the platforms you used?

What made you decide to use them yourselves?

For platforms that you have used more than once, what made you come back? What do you consider the key benefits of the service?

\section{Theme 2: Skills}

When you first started using the sharing platforms you use, was it difficult to get started? Where there any obstacles?

Did you have the feeling you knew enough about the service to start using it? Did you feel insecure about anything?

Could you imagine what might be difficult for others to use the sharing services? What could be obstacles for others to overcome?

Did you learn anything by using the sharing services? Is there anything you know now or can do better now that you have used them?

\section{Theme 3: Exit/Non-Use}

When you first started using the sharing platforms you use, was it difficult to get started? Where there any obstacles?

Did you have the feeling you knew enough about the service to start using it? Did you feel insecure about anything?

Could you imagine what might be difficult for others to use the sharing services? What could be obstacles for others to overcome?

Did you learn anything by using the sharing services? Is there anything you know now or can do better now that you have used them? 


\section{Theme 4: Discrimination}

Thinking about the last time you used the service? Did you have any special preferences in terms of your provider? In terms of gender? Age? Anything else?

Do you think users should be allowed to choose who they share with? Should they be allowed to select by gender? Select by age? Select by race? Why?

Have you experienced discrimination yourself?

\section{Theme 5: Attitudes}

In general, what is your attitude towards the "sharing economy"? Do you think it is a good thing or a bad thing? Why?

What about your social environment? Do your friends or family have any particular attitude or opinion about the sharing economy?

Is the sharing economy ever a topic of conversation? Can you recall any discussions about it?

In general, do you think the sharing services you know are trustworthy?

\section{Theme 6: Outcomes}

Thinking about your experience with the sharing economy to date, what would you say are its key impacts on you? Has anything changed for you personally due to the sharing economy?

Do you expect any such changes?

\section{Privacy Questionnaire}

\section{General Privacy Questions}

Let's come back to the question of privacy. How did you feel about signing up at a sharing service? What data did you have to provide?

How would you feel about using a different sharing service, e.g. taking an Uber ride or sleeping in an Airbnb apartment? Would you find it strange to interact with the provider, compared to a professional taxi driver or hotel staff?

How would you feel about offering a sharing service, e.g. transporting someone in your car or hosting someone in your apartment?

\section{Theme 1: Information Sharing}

What information do you share on your profile, in order to access the service you want? What would you never share?

If you were a provider within the sharing economy, what information would you share on your profile? What would you never share?

What kind of information are you likely to share privately (such as in a message conversation) that you're not going to share on your profile?

\section{Theme 2: Feedback Systems}

Assume that your matching consumer/provider has zero ratings and reviews what information would you look for, in their profiles?

What would convince you to pick them? What if it would have full stars instead? 


\section{Theme 3: Personal Boundaries}

When you offer something on a sharing platform, other people will access and use your goods. Do you perceive this as an invasion in your private sphere? Do you think it makes a difference what kind of good it is? How? Do you think it plays a role how much attached you are to this good? Why so?

As a provider, how would you manage your privacy? Or in other words, how would you make sure that you keep the boundaries for your personal sphere or belonging to a good?

\section{Theme 4: Data Safety}

There are different forms of platforms out there. Some are highly professionalized and profitable. Do you have less privacy concerns with these corporations? Or are you more skeptical regarding privacy when corporate interests are involved? Why?

Some of these platforms are less professional and not profit oriented. Do you think your data is safe with these kind of platforms? Why?

Would you welcome that - or do you welcome when - platforms give you some sort of flexibility what kind of data you want to provide. For example, pictures, visibility outside the platform (so other people do not find out you are on AirBnB, for example)? What other forms of influence would you like to have on privacy settings (e.g., filters, etc.)?

\section{Theme 5: Experiences with privacy invasion}

Maybe: What experiences have you made in the past when you thought your privacy was invaded? Do you know of other people having their privacy being invaded in sharing economy services? How did they react?

\section{Power Questionnaire}

\section{Theme 1: Voice}

Do you/Would you read the terms and conditions when signing up to a sharing service? Why? Why not?

What do you think about terms and conditions? Are they fair? Balanced? Opaque?

Do you think that people who share in the sharing economy (e.g. Uber drivers, Airbnb hosts) should be considered employees? Why? Why not?

How would knowing your provider was considered an employee change how you behave? Do you know other people who take part in the sharing economy? If so, in what ways do you discuss your use of the sharing economy with them?

Have you ever engaged in online communities or on social media to talk about your use of the sharing economy? If so, why? What did you talk about? How was it useful to you?

If you had a complaint about a sharing economy service, were you able to contact the service provider? Were they helpful? Was it easy to contact them?

Who should decide how much it costs to share?

Do you think sharing economy providers are fairly paid? What do you think is a fair 'cut' for the platform to take? 


\section{Theme: Algorithms}

On many sharing platforms, you are asked to provide ratings or feedback. Do you normally provide ratings or feedback? Why? Why not?

What do you think about the accuracy of ratings?

How do you feel about being rated yourself?

Should users with a bad rating be restricted from participating in a service? Why? Why not?

Should users with a good rating should be rewarded? Why? Why not?

Do you do anything to improve your rating?

When you are providing, who is your boss?

How do/would you expect the provider to act? With a service mentality? As a friend?

How do/would you expect the consumer to act? As a friend? As a customer?

How do you view the relationship between yourself and the provider/yourself and the consumer? If you search for a listing on Airbnb or look for a ride through Uber, do you filter the results? If so, how?

How user-friendly do you think the navigation is for the sharing sites you use?

\section{Theme: Regulation}

Do you follow media coverage about the sharing economy?

Think about the last service you used. Do you know if it is a non-profit? Collective? Profit-driven?

Would knowing change your opinion of the service? Would it change your mind on whether to take part?

Would knowing that a platform was illegal affect your decision to use it?

Should home-sharing companies have the same regulations as hotels? Why? Why not?

Should ride-hailing companies have the same regulations as taxis? Why? Why not?

Should sharing economy companies have to follow existing regulations? Tax regulations? Insurance regulations? Anti-discrimination regulations?

Should cities do more or less to regulate sharing economy companies?

Can you think of any benefits that sharing economy companies have brought?

\footnotetext{
1 „Ich habe damals oft in meinem Erststudium Leute mitgenommen nach Hause bzw. Umgebung. Und bin dann teilweise echt oft einfach umsonst gefahren, wenn man so will. Weil sobald man schon zwei oder drei, oder zwei Leute alleine schon, im Auto hatte, hatte man so die Marge, die man eben für die Tankfüllung brauchte und noch ein bisschen mehr."

2 „Cerco una convenienza reale, Rispetto ad Airbnb, apro la piattaforma guardo mille cose, poi cerco un altra cosa e scelgo quello che mi conviene di più e quindi diciamo che, rispetto ad un servizio che mi viene offerto per cui pago, però mi aspetto una convenienza se c'è la sharing economy cioè proprio perché é basato sulla fiducia. cioè se devo andare a condividere, e se posso invece a metterci niente di mio ed avere un servizio offerto vado dal servizio offerto. "

3 "Also es ist super, ja wie soll man sagen, geschäftlich einfach schon angelegt, habe ich so den Eindruck - auch über Airbnb. Und auch Leute, bzw. das sind ja dann trotzdem Privatpersonen, aber die sich da quasi so ein zweites Standbein aufgemacht haben."
} 
4 „Però effettivamente sono stata in Erasmus e li ho usato Blablacar, ed è stato molto più naturale che usare I treni locali. Rispetto all'Italia... che comunque a parte la minore conoscenza del sistema ferroviario, la lingua e tutto il resto, è stato più facile usare Blablacar."

5 „Und tatsächlich bei so Städte-Trips oder sowas, wo ich AirBnB vorzugsweise genutzt habe. Bei sowas hat man schon auch das Gefühl, man lernt das irgendwie auch ein bisschen cooler kennen. Man wohnt ein bisschen authentischer. Also dieses ganze Image-Ding worauf die so gehen, greift schon finde ich. Dass man das Gefühl hat, man ist da ein bisschen mehr drin. Man wohnt in einem normalen Wohnhaus und nicht irgendwie in einem Hotelkomplex. Und kann ja da kochen und geht irgendwie ganz normal raus und einkaufen und so. Finde ich, da hat man schon immer mehr das Gefühl, normaler Teil der Stadt zu sein, wenn man mal in einen Supermarkt geht, als wenn man jetzt immer nur Essen geht oder irgendwie sowas. Insofern finde ich das zum Reisen schon irgendwie schon eine neue Alternative quasi. So ein bisschen authentischer und auch irgendwie jünger die Stadt kennenzulernen."

${ }^{6}$ „Ich muss sagen bei Airbnb ist es mir super wichtig, da eine Bewertung zu schreiben. Weil da wären wir wieder bei diesem Privatsphäre-Aspekt. Da gibt dir jemand Zugang zu seiner Wohnung und ein Stück weit zu seiner Welt und ganz viele geben sich ganz viel Mühe, legen da Handtücher hin und was weiß ich. Und dann finde ich dieser Kommentar ist eine Art der Wertschätzung und irgendwie ein Dankeschön dafür."

7 „Ist halt vermutlich mit dem Grundgedanken gestartet Ressourcen vernünftig zu nutzen, aber hat sich dann kommerzialisiert und professionalisiert, weil Menschen gemerkt haben: Ok ich kann das irgendwie zu meinem Vorteil nutzen."

8 „Ich denke grade auch der Aspekt, dieser gesellschaftliche Wohlstand und dieser Überfluss an Dingen, die man besitzt, aber gar nicht unbedingt alle braucht, war der Startpunkt von dem Ganzen. Und den haben sich natürlich früher oder später viele Unternehmen zu Nutze gemacht und sind da halt mit aufgesprungen."

9 „Auf der anderen Seite ändert sich bei Blablacar zum Beispiel auch, dass die Fahrten immer teurer werden. Das was am Anfang mal für 12 Euro oder so angeboten wurde kostet jetzt auch fast so viel wie die Bahn an manchen Tagen. Also wenn ich da abwäge, ob ich die Bahn nehme oder Blablacar, habe ich nicht immer einen großen Kostenvorteil."

10 „Poi quando ho cambiato telefono non mi è più capitato di riscaricarlo [uber] e quindi ho sempre trovato altre soluzioni per i miei spostamenti. Da un lato c'è l'abitudine e l'esigenza immediata e quando c'è l'esigenza immediata sì, scarichi anche apposta e poi finisce li."

11 „È proprio un problema di conoscere la piattaforma nelle grandi città si conoscono più queste cose, l'amico che ne parla. Mentre invece nel paese nella mia cerchia ristretta tutti cercano un determinato hotel, perché si fa cosi. "

12 „Più che altro magari serve una persona che introduca le altre a questo utilizzo. Spesso e volentieri capita che un mio amico mi dica 'prova Blablacar'. Perché un altro mio amico vuole andare a Torino cosi ci vai."

13 "Quando vado in università a Milano di solito ci vado in macchina con altri studenti del mio paese. Siamo d'accordo che quando si va in università si va assieme."

14 „Io recentemente ho ospitato un amico di alcuni amici, quindi una sorta di couchsurfing improvvisato, Doveva venire qui e gli serviva una sistemazione [...] quindi mi chiedono questo favore e dico sì. Bene è arrivato questo ragazzo, gli ho lasciato camera e ho detto si fai come fossi a casa tua le lenzuola sono lì. "

15 „Ich glaube, ich hatte in [deutsche Stadt] eben zwei Wohnungen angefragt, die erste wurde eben abgelehnt, aber es lag anscheinend, oder glaub ich eher daran, dass sie eben - also es war eine Frau, die selbst auch in der Wohnung gelebt hat und zusätzlich noch eine weibliche Person eben haben wollte. Das war aber tatsächlich das einzige Mal. Sonst wurden die Buchungen eigentlich immer bestätigt."

16 "Chi vive in provincia fatica un po' a trovare, io apro Blablacar guardo dalla mia città di origine per andare in un posto e trovo molto poche opportunità rispetto che cercando da Milano. “ 
17 „(...) zum Beispiel Airbnb kann ich ja nur nutzen, wenn ich eine Kreditkarte habe. (...) Ich muss ein Bankkonto haben, ich muss in dieses System eingebunden sein. Und wenn man das hat, kann man es auch nutzen und man muss einen Computer haben."

18 „Ich spekuliere immer darauf, dass sich dann jemand anderes für mich da anmeldet. Also wenn man es mit einer Gruppe benutzt. Weil ich (unv.) und auch gar nicht so gern meine Daten rausgebe, weil ich eben nicht weiß, was mir da in United Kingdom damit passiert. Also es geht jetzt nicht um den Jetzt-Zustand, aber irgendwann mal und mir wäre es halt glaube ich sehr unangenehm, wenn das meine beruflichen Aussichten irgendwann mal torpedieren könnte, deswegen halte ich mich sehr mit digitalem Konsum und Datenweitergabe zurück und hoffe immer, dass in der Gruppe einer einen Account besitzt."

19 „Wie ist das dann bei Airbnb? Wenn ich da meine Wohnung vermiete und immer im großen Stil und was weiß ich. Das haben die ja jetzt auch kritisiert, dass zum Beispiel in Deutsche-Stadt-B oder ich kenne es jetzt aus einem aktuellen Beispiel aus Niederländische-Stadt-A, dass einfach da Leute sich daran bereichern und es eigentlich überhaupt kein SharingGedanke ist, sondern einfach nur "Ich habe etwas und du gibst mir Geld dafür". Das hat ja mit Sharing dann nicht mehr so viel zu tun."

20 „Pensi che tutto sia temporaneo quindi sei disposto a condividere una parte della tua vita, fare conversazione ma ti aspetti che finisca presto."

21 „È come quando viaggi in treno e una vecchietta vuole fare conversazione, ci parli ma non ci diventi amico.“

22 „Und dass es da auch, wenn man über Regulierung spricht, auch höhere Strafen, Abschreckung et cetera gibt. Weil diese ganzen Sachen haben eben auch Nachteile, aber für Privatpersonen, die das wirklich nur anbieten. Wobei der Grad natürlich immer schwierig ist, aber für Privatpersonen bin ich jetzt nicht für höhere Regulierungen, weil das diesen Gemeinschafts-, diesen Sharing-Gedanken irgendwie bürokratisiert einfach."

23 „Ökologie ist natürlich nicht nur an Sharing Economy gekoppelt, aber ich denke, dass mehrfach Sharing Economy ökologisch sein kann und dass es alle drei Aspekte von Nachhaltigkeit hat: finanziell günstiger ist, dass es weniger Ressourcen braucht und dass es mehr gesellschaftliche Interaktionen ermöglicht. Das muss nicht sein, kann Nebeneffekte haben aber im Idealfall kann es das bringen."

24 „Bei mir (...) ich stehe dem immer noch positiv gegenüber aber ich weiss auch wieviel ich preisgeben will. Vordergründig zumindest, man weiss ja nie so ganz genau was im Hintergrund passiert. Ich würde nie noch mehr preisgeben wollen. (...) Ich will das eigentlich nur nutzen und wenig zurückgeben."

25 „A me personalmente dà fastidio tutto questo controllo sulla privacy, perché poi alla fine è irreale (...) infatti mi sembra un ossimoro parlare di privacy"

26 „Ja, ihr könnt das alles in euren Privatseinstellungen tätigen etc." aber letzten Endes, was da im Hintergrund passiert. Klar müssen die sich irgendwie an die Gesetze halten, aber so richtig nachvollziehen kann man es irgendwie nicht"

27 „Ich hätte vielleicht noch einmal eine Unterscheidung gemacht zwischen dem Auto als Privatsphäre und Airbnb. Weil ich finde, wenn ich jetzt in eine andere Wohnung eintrete ist das deutlich mehr Privatsphäre, als wenn ich jetzt in ein Auto, welches ja auch gemietet sein kann, gehe. Und bei Airbnb, was ich auch schon manchmal genutzt habe, ist es eben so, dass es sich schon erstmal finden muss: Inwieweit kann ich die Küche mitbenutzten, kann ich jetzt mit denen länger reden, kann ich vielleicht nach oben gehen."

28 „Ich mach es nur, wenn ich was buche. In der Nachricht schreibe ich dann über mich selbst ein bisschen und was ich denn in der Stadt überhaupt mache. Aber nicht in meinem Profil."

29 „Meistens über einen relativ langen Zeitraum deswegen macht man es vielleicht ein bisschen aus - naja was heißt Scham. Aber ja genau, man kann ja eigentlich nicht nichts sagen, wenn jetzt jemand die ganze Zeit etwas fragt. Du kannst ja nicht einfach nicht antworten - das geht ja gar nicht. Also insofern bist du ja gezwungen, irgendwie einen Dialog zu halten." 
30 "Ich glaube ich würde jetzt auf den Schreibstil achten - also jetzt noch nicht mal ob das korrekt oder nicht korrekt geschrieben ist, sondern einfach schon mal ob jemand, keine Ahnung, das einigermaßen höflich formuliert oder ob jemand schon mal nett schreibt oder nicht nett schreibt. Gibt es ja auch Unterschiede. "

31 „Allora sono un po' diffidente in generale, credo che guardare una persona nel modo come si presenta anche in una foto se c'ha la camicia piuttosto che la maglia bucata dici forse è un po' più affidabile rispetto ad uno che magari cha la foto al volante e c'ha in mano una birra... Non lo so e per questo, sì può avere anche recensioni ma io non ho... non lo so"

32 „Ja und halt ganz viel auch die Kommentare von den anderen Nutzern. Die beschreiben ja voll oft die Person an sich. Ob die nett war oder nicht und man traut dann irgendwie trotzdem nochmal einer neutralen Person, die den anderen bewertet mehr, als das was er über sich selbst schreibt. weil er würde ja jetzt selbst nicht schreiben: "Ich bin unhöflich."

33 „I ho avuto esperienze positive su Airbnb ma perché fondamentalmente è colui che ti ospita che deve incanalare dentro di sé la filosofia del servizio."

34 „Und das ist halt dieses, dass ich inn dann entertainen muss während der Fahrt, mich dann durchgehend mit ihm unterhalten muss. Was ja auch wirklich dann meistens auch immer ganz interessant und cool ist, aber irgendwie muss man echt Lust drauf haben. Manchmal fährt man halt sonntags zurück und denkt sich halt: "Eigentlich habe ich gerade gar keine Lust mit jemandem zu reden'“

35 „Also zum Beispiel bei mir ist es mit dem BlaBlaCar, Mitfahrgelegenheit tatsächlich so, dass ich halt lieber mit der Bahn fahre, weil ich da weiß, dass ich mein Zeug machen kann und meine Ruhe habe und eben nicht vier Stunden Smalltalk halten muss. Also ich habe jetzt nichts gegen intermenschliche Interaktion aber ich finde es halt richtig anstrengend, wenn man sich mit den Leuten nicht versteht und manchmal ist man auch einfach müde, wenn man im Auto sitzt“.

36 "Ich habe einmal einen Stern weniger, also jetzt nicht richtig schlecht, aber ich fand es unfair, weil es war ein sehr kleines Auto und ich bin nun mal recht groß und wollte dann gerne vorne auf dem Beifahrersitz mit sitzen, weil ich nun mal die längsten Beine von allen hatte. Und dann hat der Fahrer mir dann noch geschrieben, dass ich auch recht viele Ansprüche gestellt hätte. Und wenn jetzt keine Rückenschmerzen zu haben schon ein Anspruch ist, dann bin ich Anspruchsvoll, ja. “

37 „Aber ich würde glaube ich nur etwas bewerten, wenn mir etwas extrem schlecht aufgefallen wäre oder sowas von positiv, dass ich so begeistert bin, dass ich das irgendwie der Welt mitteilen müsste. "

38 "Es gibt ja bestimmt auch Bewertungen, die fake sind oder vom Hotelier oder vom Anbieter selbst sind, da muss man natürlich auch ein wenig aufpassen aber ich finde schon, dass ist extrem wichtig."

39 „Naja du hast auch unpünktliche Mitfahrer und für dich als Fahrer - dann hat der ständig nur schlechte Bewertungen, dass derjenige nicht gekommen ist, dann finde ich hat das schon Vorteile."

40 „Bei AirBnB weiß man letztendlich - von den Bildern her kann man es einschätzen, aber, wenn man da ankommt weiß man dann trotzdem nicht, was einen da erwartet. “

41 „Für mich ist es noch einen Punkt. Jeder Ort ist anders. Wenn man einmal übernachtet kann es sein, dass man sagt, ich will den Tag z. B. in den USA, an einem Ort für Freizeit nutzen und man merkt, die Person sagt jetzt, «nein jetzt kannst du noch nicht kommen, komm zwischen 11 und 12». Dann ist sie aber nicht da, sondern nur der Nachbar, der gibt mir das und dann sage ich, wo kann ich schlafen, «ach das weiss ich nicht das ist jemand anders». Dann gehe ich rein, dann liegt dort der Zettel, aber der Schlüssel passt nicht mehr oder ich muss den Schlüssel irgendwo einfach in einen Briefkasten legen. Ich denke, aber meinen Computer und meine Sachen dabei. Das ist ja überhaupt keine Sicherheit"

42 „Aber dieser Prozess, dass wirklich weiß, dass man für irgendwas haftet, wenn was schief läuft. Also wenn man wirklich irgendwie, ja jetzt blöd gesagt eine Kerze anlässt und auf einmal fackelt die ganze Wohnung: Was passiert denn dann da? Und wer ist dann dafür verantwortlich? Ich glaube darüber ist man sich ganz oft, dadurch dass du so einen kurzen Prozess zwischen Buchung und Vertragsabschluss hast, auch gar nicht mehr so richtig bewusst. Da könnte ich mir zumindest vorstellen, dass es auch ein Grund ist für viele Leute, die dann sagen „Nja, da lass ich vielleicht mal lieber die Finger von”

43 „Das Zimmer, wenn man Räume vermietet und es kommt jemand und macht das Zimmer kaputt, der Vertrag hat nichts mit dieser Plattform zu tun. Er ist zwischen der Person die das Zimmer vermietet und der Person die das Zimmer mietet. 
Das heisst, wenn die am nächsten Tag nach Asien zurück fliegt und das halbe Zimmer fehlt, dann ist der Vertrag zwischen dir und der Person entstanden. "

44 „Und zwar mit Uber - habe ich hier vergessen - nutze ich auch regelmäßig gerne, zum Beispiel in Thailand. Und hatte auch die negative Erfahrung, dass die viel von der Polizei auch gesucht werden beziehungsweise auch Schutzgeld. Und da ist es meistens so (Lachen im Hintergrund) das Uber in vielen Ländern rein rechtlich, also als Fahrer ist man sich nicht sicher, in welchen Ländern das eigentlich rechtlich erlaubt ist. Man weiß es über die Presse, in Deutschland funktioniert es nicht, in den USA funktioniert es gut. In Thailand werden die teilweise von den Polizisten sehr genau kontrolliert. Und während der Uber-Fahrt ist dort ein Polizist bei uns reingekommen und wir mussten so tun als ob wir irgendwelche anderen abgesprochenen Fahrten hätten, weil uns der Fahrer gebrieft hat. Also da fühlt man sich auch ein bisschen unwohl, dann sagen zu müssen: ok, man ist gar kein Uber-Nutzer, nur um den halt irgendwie zu schützen."

45 „Ich finde aber so über die Jahre hat sich das Ganze halt immer mehr professionalisiert. Ich finde am Anfang, auch mit Airbnb, hatte ich viel mehr Kommunikationsprobleme: Wie kommt man in die Wohnung, wo ist der Schlüssel und so weiter. Auch mit damals noch Mitfahrgelegenheit: Wo trifft man sich. Und inzwischen ist es halt so vorprogrammiert, dass man irgendwie nach dem Treffpunkt fragen kann und man muss gar nicht mehr selber einen Text schreiben, sondern man klickt das einfach an und die Kommunikation wurde halt insgesamt einfach professionalisiert"

46 „Regolamentare, dare un nome alla cosa se sono freelance e sto partecipando ad una cosa di sharing economy ok va bene perché io sto facendo, un di più una cosa che comunque mi piace, sulla quale si guadagna ma non in maniera eccessiva o giusta come vogliamo dire. Dall'altro lato chiamarlo dipendente... io sono dipendente di tizio come dipendente lavoro tot ore chiedo che vengano retribuite il giusto"

47 "Comunque vedevo anche sui vari articoli che loro lamentavano il fatto che non riuscivano comunque ad arrivare a fine mese" 